\title{
Helium and lead isotopes reveal the geochemical geometry of the Samoan plume
}

\author{
M.G. Jackson ${ }^{1}$, S.R. Hart ${ }^{2}$, J.G. Konter ${ }^{3}$, M.D. Kurz ${ }^{4}$, J. Blusztajn ${ }^{2}$, K.A. Farley ${ }^{5}$ \\ ${ }^{1}$ Univeristy of Calfornia Santa Barbara, Department of Earth Science, Santa Barbara, \\ CA, 93109-9630 USA \\ ${ }^{2}$ Woods Hole Oceanographic Institution, Department of Marine Geology and \\ Geophysics, Woods Hole, MA, 02543 USA \\ ${ }^{3}$ University of Hawaii, Manoa, SOEST, Honolulu, HI, USA \\ ${ }^{4}$ Woods Hole Oceanographic Institution, Department of Marine Chemistry, Woods Hole, \\ MA, 02543 USA \\ ${ }^{5}$ California Institute of Technology, Division of Geological and Planetary Sciences, \\ Pasadena, CA, 91125 USA
}

Hotspot lavas erupted at ocean islands exhibit tremendous isotopic variability, indicating that there are numerous mantle components ${ }^{1,2}$ hosted in upwelling mantle plumes that generate volcanism at hotspots like Hawaii and Samoa $^{3}$. However, it is not known how the surface expression of the various geochemical components observed in hotspot volcanoes relates to their spatial distribution within the plume $\mathrm{e}^{4-10}$. Here we present a unique relationship between He and $\mathrm{Pb}$ isotopes in Samoan lavas that places severe constraints on the distribution of geochemical species within the plume. In Pb-isotopic space, the Samoan data form several distinct geochemical groups, each corresponding to a different geographic lineament of volcanoes. Each group has signatures associated with one of four mantle endmembers with low ${ }^{3} \mathrm{He} /{ }^{4} \mathrm{He}$ : EMII (enriched mantle 2), EMI (enriched mantle 1), HIMU (high $\mu={ }^{238} \mathrm{U} /{ }^{204} \mathrm{~Pb}$ ) and DM (depleted mantle). Critically, the four isotopic-geographic groups converge on a common region of $\mathrm{Pb}$-isotopic space with high ${ }^{3} \mathrm{He} /{ }^{4} \mathrm{He}$. This observation is consistent with several low ${ }^{3} \mathrm{He} /{ }^{4} \mathrm{He}$ components in the plume mixing with a common high ${ }^{3} \mathrm{He} /{ }^{4} \mathrm{He}$ component, but not significantly 
with each other, otherwise the four isotopic groups would be obscured by mixing. The mixing relationships inferred from the new $\mathrm{He}$ and $\mathrm{Pb}$ isotopic data paint the clearest picture yet of the geochemical geometry of a mantle plume, and are best explained by a high ${ }^{3} \mathrm{He} /{ }^{4} \mathrm{He}$ plume matrix that hosts, and mixes with, several distinct low ${ }^{3} \mathrm{He} /{ }^{4} \mathrm{He}$ components.

Lavas erupted at oceanic hotspots - thought to sample melts from buoyantly upwelling mantle plumes ${ }^{3}$ — are isotopically heterogeneous and provide definitive evidence that the Earth's mantle is compositionally diverse and hosts several distinct geochemical "species"1,2. Radiogenic isotopic studies of ocean island basalts (OIB) erupted at hotspots identify a multitude of mantle compositions that are often broadly grouped into four end members with different isotopic taxonomies: EM2, EM1, HIMU, and DM. A fifth component, characterized by high ${ }^{3} \mathrm{He} /{ }^{4} \mathrm{He}$ ratios, is also identified in $\mathrm{OIB}^{11}$, and has been variously called undegassed mantle ${ }^{12}$, FOZO (Focus Zone ${ }^{13}$ ), PHEM (Primitive Helium Mantle $\left.{ }^{14}\right)$, or C $\left(\right.$ Common $\left.^{15}\right)$. Unfortunately, the spatial distribution of these mantle components within upwelling mantle plumes is difficult to infer using geochemical studies of surficially-erupted basalts.

Recent efforts to examine the spatial distribution of mantle plume geochemical heterogeneities have focused on the geographic distribution of isotopic compositions along the surface volcanic traces of hotspot tracks. These studies have yielded significant progress relating the distribution of isotopic compositions in surface lavas to the spatial distribution of isotopic components within an upwelling mantle plume. A geographic separation of isotopic compositions is famously illustrated at the Hawaiian hotspot, where two parallel volcanic lineaments-Loa and Kea-exhibit isotopically resolveable compositions $^{4-6,16}$. The isotopic and geographic separation of the Loa and Kea volcanic lineaments is suggested to reflect spatial separation of the mantle components within the plume that give rise to the two isotopically-distinct volcanic lineaments, possibly related 
to the compositional structure of the deepest mantle ${ }^{5,6}$. Similar observations of geographical and geochemical separations of parallel volcanic lineaments have been made at other hotspots ${ }^{6-10,17}$. These observations suggest that the geochemical structure of many mantle plumes vary spatially in a systematic manner.

This paper focuses on the geochemical variability along the parallel volcanic lineaments of the age-progressive ${ }^{18}$ Samoan hotspot and the geochemical structure of the underlying upwelling mantle plume. We present 36 new $\mathrm{Pb}$-isotopic analyses together with new $\mathrm{Sr}, \mathrm{Nd}$ and $\mathrm{He}$ isotopic measurements (Supplementary Tables 1-3) on a suite of lavas from the Samoan hotspot (Figure 1 and Extended Data Figure 1). In ${ }^{206} \mathrm{~Pb} /{ }^{204} \mathrm{~Pb}-$ ${ }^{208} \mathrm{~Pb} /{ }^{204} \mathrm{~Pb}$ isotopic space, four isotopic groups emerge from the dataset (Figure 2), and the 4 groups converge on a common region, roughly forming an " $\mathrm{X}$ " shape. Three of the four isotopic groups are defined by shield-stage lavas from each of three volcanic lineaments: the islands and seamounts of the "Vai" volcanic lineament (blue field on map, dark blue symbols in plots) tends to form a single group in isotopic space, the "Malu" volcanic lineament (pink) clusters in another isotopic group, and subaerial lavas from the "Upo" volcanic lineament (yellow) corresponds to a third group (Figure 1). Rejuvenated-stage lavas are encountered only on the islands of Savai'i, Upolu and Tutuila that define the Upo-volcanic lineament, are younger than the shield-stage lavas on each island, and form a fourth isotopic group (turquoise). There are exceptions to this correspondence between geochemistry and geography (Methods). For example, the submarine lavas from the western region of the hotspot (dredged near Savai'i and Upolu islands) overlap with the isotopic compositions found in the Vai and Malu-volcanic lineaments further to the east and include ultra-enriched lavas ${ }^{18,19}$ unlike that found in any of the younger and more easterly volcanism (Figure 2); this enriched material includes an additional isotopic component in the Samoan plume. However, there are insufficient submarine samples from the western Samoan region to define their isotopic taxonomy or 
geographic extent, or whether the western Samoan submarine samples define separate geographic trends, and we exclude these submarine lavas from our treatment below (see Methods); this approach is similar to that taken in Hawaii, where the geochemical separation of the Loa and Kea volcanic lineaments breaks down in the western region of the Hawaiian chain, and it is common to exclude some or all of the western islands when defining the Loa and Kea lineaments ${ }^{4}$._In this paper we examine Samoan rejuvenated lavas, Vai- and Malu-lineament lavas, and the subaerial shield lavas from the Upolineament, which form 4 geochemical groups. However, submarine western Samoan lavas are shown in the figures for clarity.

The four geochemical groups identified in Samoan rejuvenated lavas, Vai- and Malu-lineament lavas, and the subaerial shield lavas from the Upo-lineament are clearly resolved as separate clusters in multiple isotopic spaces (Figure 2; Methods). Lavas from the four groups exhibit geochemical characteristics that are associated with the four canonical mantle endmembers: The Malu group has EM2 characteristics, the Vai group has HIMU characteristics (though the signature is dilute), the Upo group has geochemically-depleted characteristics (not unlike Hawaiian Mauna Kea lavas; Figure 2), and rejuvenated lavas have EM1 characteristics (see Methods).

These four endmember groups appear to converge in a region of isotopic space characterized by lavas with the highest ${ }^{3} \mathrm{He} /{ }^{4} \mathrm{He}$ values, and the ellipse describing the highest ${ }^{3} \mathrm{He} /{ }^{4} \mathrm{He}$ lavas (20-33.8 Ra, ratio to atmosphere) ${ }^{14,17,20}$ in Figure 2 serves as a common component region for the four Samoan geochemical groups (see Methods). In two and three-dimensional $\mathrm{Pb}$-isotopic space, the four $\mathrm{Pb}$-isotopic data groups overlap with the common component region at the $99 \%$ confidence level (Figure 2 and refer to Methods). Additionally, in $\mathrm{Pb}$-isotopic space, ${ }^{3} \mathrm{He} /{ }^{4} \mathrm{He}$ ratios decrease monotonically away from the common region toward the extremes of the four data groups located furthest from the common region. We quantify this relationship by calculating the 
distance from the common component in three-dimensional $\mathrm{Pb}$-isotopic space, and the distance parameter is called $\mathrm{DPb}_{6-7-8}$ (Methods). ${ }^{3} \mathrm{He} /{ }^{4} \mathrm{He}$ is highest in the common component region (low $\mathrm{DPb}_{6-7-8}$ values) and decreases away from the common component (high $\mathrm{DPb}_{6-7-8}$ ) (Figure 3).

The unique isotopic topology identified in Samoan lavas places important constraints on the distribution and mixing relationships of the various components in the Samoan plume. The data are consistent with the $10{ }^{3} \mathrm{He} /{ }^{4} \mathrm{He}$ components (i.e., $\leq 8 \mathrm{Ra}$ ) in the plume mixing with a high ${ }^{3} \mathrm{He} /{ }^{4} \mathrm{He}$ common component, and this mixing hypothesis is supported by the relationship between ${ }^{3} \mathrm{He} /{ }^{4} \mathrm{He}$ and $\mathrm{DPb}_{6-7-8}$ (Figure 3 ) and by the convergence of the four $99 \%$ confidence intervals that enclose all possible mixing trends for each group (Figure 2). However, the four low ${ }^{3} \mathrm{He} /{ }^{4} \mathrm{He}$ components do not appear to mix efficiently with each other, otherwise the four $\mathrm{Pb}$-isotopic groups would be obscured. Clearly, some mixing among the low ${ }^{3} \mathrm{He} /{ }^{4} \mathrm{He}$ components has occured, and this might explain some of the scatter in the isotopic groups; several Vai-lineament lavas have the isotopic composition expected for lavas from the Malu lineament, and viceversa, but overall such "cross-fertilization" among the low ${ }^{3} \mathrm{He} /{ }^{4} \mathrm{He}$ components is limited (Methods).

We propose a conceptual model for the geochemical geometry of the Samoan plume that is consistent with the mixing relationships suggested by the unique isotopic topology. In the model, several low ${ }^{3} \mathrm{He} /{ }^{4} \mathrm{He}$ components are hosted in a plume matrix composed of high ${ }^{3} \mathrm{He} /{ }^{4} \mathrm{He}$ material, so that each of the low ${ }^{3} \mathrm{He} /{ }^{4} \mathrm{He}$ components can mix with the high ${ }^{3} \mathrm{He} /{ }^{4} \mathrm{He}$ plume matrix (Figure 4). The low ${ }^{3} \mathrm{He} /{ }^{4} \mathrm{He}$ components must be sufficiently isolated from each other within the plume so they do not easily mix, either as solids or as liquids. In order to achieve the geographic separation of the Vai and Malu lineaments, we suggest that bilateral heterogeneity, like that proposed for the Hawaiian plume ${ }^{4}$, must also exist in the Samoan plume: the component responsible for the Vai 
lineament must be located on the northern side of the plume and the component generating the Malu lineament must be located on the southern side (Figure 4). The components are separated by sufficient distance within the Samoan plume so that they do not mix efficiently. The Upo-lineament component was located higher in the Samoan plume than the Vai and Malu components, as most Upo-lineament lavas were erupted before onset of Vai- and Malu-lineament volcanism (Figure 4). Components that have geochemical fingerprints similar to those identified in Malu and Vai volcanic lineaments are also identified in the submarine portion of the western Samoan islands of Savai'i and Upolu $^{18,19}$, suggesting that the EM2 and HIMU geochemical components show up periodically in the plume and are not strictly limited to the Malu and Vai volcanic lineaments. Finally, rejuvenated lavas may sample a component located in the Samoan plume that is underplated on the mantle lithosphere beneath Samoa ${ }^{17}$, or a component hosted in the mantle lithosphere beneath the Samoan hotspot ${ }^{21}$, and is therefore not shown in Figure 4. However, if the rejuvenated component is hosted in the mantle lithosphere, an important question is how it survives the high melt flux during shield stage volcanism.

Preservation of four low- ${ }^{3} \mathrm{He} /{ }^{4} \mathrm{He}$ components in the upwelling Samoan plume, as indicated by the unique isotopic topology identified in Samoan lavas, presents an important problem. Dynamic modelling suggests that components embedded in a plume matrix will be "stretched out" during plume ascent ${ }^{22}$, so that the components ultimately resemble "spaghetti" with their long axes oriented in a direction parallel to plume motion $^{4,23}$ : the stretching has been shown to preserve the initial separation of components within a plume, so that their spatial relationships in the plume are preserved during upwelling from the deep mantle $\mathrm{e}^{22}$. In this way, the different components are not mixed chaotically in the ascending plume conduit, and it is possible for various components to remain isolated from each other within the plume matrix. Alternative plume structures 
have been discussed for the Hawaiian plume in which the high ${ }^{3} \mathrm{He} /{ }^{4} \mathrm{He}$ material is at the innermost core of the plume and lower ${ }^{3} \mathrm{He} /{ }^{4} \mathrm{He}$ components are on the periphery of the plume ${ }^{24}$, but such a geometry would allow the low ${ }^{3} \mathrm{He} /{ }^{4} \mathrm{He}$ components to mix, which is difficult to reconcile with the isotopic topology of Samoan lavas.

In multi-isotopic space, different hotspots trend to a common region, called $\mathrm{FOZO}^{13}$ or $\mathrm{C}^{15}$, characterized by high ${ }^{3} \mathrm{He} /{ }^{4} \mathrm{He}$. Curiously, the isotopic topology of Samoan lavas represents a microcosm of the global OIB dataset, in which the various geochemical groups in multi-isotopic space converge on a common region characterized by high ${ }^{3} \mathrm{He} /{ }^{4} \mathrm{He}$. At the global scale, this isotopic topology is consistent with high ${ }^{3} \mathrm{He} /{ }^{4} \mathrm{He}$ plumes entraining low ${ }^{3} \mathrm{He} /{ }^{4} \mathrm{He}$ components in the deep mantle ${ }^{13}$, perhaps in the Pacific large low shear-wave velocity province (LLSVP) that underlies Samoa, which is suggested to host high ${ }^{3} \mathrm{He} /{ }^{4} \mathrm{He}^{25,26}$. The low ${ }^{3} \mathrm{He} /{ }^{4} \mathrm{He}$ components in the Samoan plume are associated with subducted materials (Methods)_oceanic crust, mantle lithosphere and sediments - which may also reside in "slab graveyards" at the bottom of the mantle where plumes originate ${ }^{27}$. We cannot rule out a model where the high ${ }^{3} \mathrm{He} /{ }^{4} \mathrm{He}$ component may be located deeper than the lower ${ }^{3} \mathrm{He} /{ }^{4} \mathrm{He}$ components, and the latter components are incorporated by high ${ }^{3} \mathrm{He} /{ }^{4} \mathrm{He}$ plumes at shallower mantle depths ${ }^{15}$. However, it is not clear how the low ${ }^{3} \mathrm{He} /{ }^{4} \mathrm{He}$ components in the Samoan plume would avoid significant admixture with each other during entrainment from below, as entrained products will remain on the periphery of the plume during upwelling and might interact with subsequently entrained material. If entrainment into the high ${ }^{3} \mathrm{He} /{ }^{4} \mathrm{He}$ plume matrix occurred in the plume source, dynamic models suggest that it must be a non-turbulent process that prevents the low ${ }^{3} \mathrm{He} /{ }^{4} \mathrm{He}$ components from mixing with each other ${ }^{22}$.

Full Methods and any associated references are available in the online version of the paper at www.nature.com/nature. 


\section{References}

1. Zindler, A., \& Hart, S. Chemical geodynamics. Annu. Rev. Earth Planet. Sci. 14, 493571 (1986). doi:10.1146/annurev.ea.14.050186.002425.

2. Hofmann, A. in The Mantle and Core (ed Carlson, R.W.) 61-101, Vol. 2 of Treatise in Geochemistry (Elsevier, Amsterdam, 2003).

3. Morgan, W. J. Convection plumes in the lower mantle. Nature 230, 42-43 (1971).

4. Abouchami, W. et al. Lead isotopes reveal bilateral asymmetry and vertical continuity in the Hawaiian mantle plume. Nature 434, 851-856 (2005).

5. Weis, D., Garcia, M.O., Rhodes, J.M., Jellinek, M., \& Scoates, J.S. Role of the deep mantle in generating the compositional asymmetry of the Hawaiian mantle plume. Nature Geoscience 4, 831-838 (2011). doi:10.1038/ngeo1328.

6. Huang, S., Hall, P.S., \& Jackson, M.G. Geochemical zoning of volcanic chains associated with Pacific hotspots. Nature Geoscience 4, 874-878 (2011).

7. Payne, J.A., Jackson, M.G., \& Hall, P.S. Parallel volcano trends and geochemical asymmetry of the Society Islands hotspot track. Geology 41, 19-22 (2013).

8. Rohde, J., Hoernle, K., Hauff, F., Werner, R., O’Connor, J., Class, C., GarbeSchönberg, D., Jokat, W. 70 Ma chemical zonation of the Tristan-Gough hotspot track. Geology 41, 335-338 (2013).

9. Harpp, K.S., Hall, P.S., \& Jackson, M.G. in The Galápagos: A National Laboratory for the Earth Sciences (eds Mittelstaedt, E., Graham, D., d’Ozouville, N. \& Harpp, K.) 2740 (AGU, Washington, DC, 2014). In press. 
10. Chauvel, C. et al. The size of plume heterogeneities constrained by Marquesas isotopic stripes. Geochem., Geophys., Geosyst., 13 (2012). Q07005, doi:10.1029/2012GC004123

11. Stracke, A., Hofmann, A.W., \& Hart, S.R. FOZO, HIMU and the rest of the mantle zoo. Geochem. Geophys. Geosyst. 6. (2004). doi:10.1029/2004GC000824

12. Kurz, M.D., Jenkins, W.J., Hart, S.R. Helium isotopic systematics of oceanic islands and mantle heterogeneity. Nature 297, 43-47 (1982).

13. Hart, S.R., Hauri, E.H., Oschmann, L.A.,\& Whitehead, J.A. Mantle plumes and entrainment: isotopic evidence. Science 256, 517-520 (1992).

14. Farley, K.A., Natland, J.H., \& Craig, H. Binary mixing of enriched and undegassed (primitive?) mantle components ( $\mathrm{He}, \mathrm{Sr}, \mathrm{Nd}, \mathrm{Pb})$ in Samoan lavas. Earth Planet. Sci. Lett. 111, 183-199 (1992).

15. Hanan, B.B., \& Graham, D.W. Lead and helium isotope evidence from oceanic basalts for a common deep source of mantle plumes. Science 272, 991-995 (1996).

16. Tatsumoto, M. Isotopic composition of lead in oceanic basalt and its implication to mantle evolution. Earth Planet. Sci. Lett. 38, 63-87 (1978). doi:10.1016/0012$821 X(78) 90126-7$.

17. Workman, R. K. et al. Recycled metasomatized lithosphere as the origin of the Enriched Mantle II (EM2) endmember: evidence from the Samoan volcanic chain. Geochem. Geophys. Geosyst. 5 (2004). doi:10.1029/2003GC000623 (2004).

18. Koppers, A.A.P., Russell, J.A., Jackson, M.G., Konter, J., Staudigel, H., \& Hart, S.R. Samoa reinstated as a primary hotspot trail. Geology 36, 435-438 (2008). 
19. Jackson, M. G. et al. The return of subducted continental crust in Samoan lavas. Nature 448, 684-687 (2007b).

20. Jackson, M. G., Kurz, M. D., Hart, S. R., \& Workman, R. K. New Samoan lavas from Ofu Island reveal a hemispherically heterogeneous high ${ }^{3} \mathrm{He} /{ }^{4} \mathrm{He}$ mantle. Earth Planet. Sci. Lett. 264, 360-374 (2007a). doi : 10.1016/j.eps1.2007.09.023.

21. Konter, J.G., \& Jackson, M.G. Large volumes of rejuvenated volcanism in Samoa: Evidence supporting a tectonic influence on late-stage volcanism. Geochem., Geophys., Geosyst. 13 (2012). doi:10.1029/2011GC003974.

22. Farnetani, C.G., Hofmann, A.W., \& Class, C. How double volcanic chains sample geochemical anomalies from the lowermost mantle. Earth Planet. Sci. Lett. 359, 240-247 (2012).

23. Harpp, K.S., Geist, D.J., Koleszar, A.M., Christensen, B., Lyons, J., Sabga, M., \& Rollins, N. in The Galápagos: A National Laboratory for the Earth Sciences (eds Mittelstaedt, E., Graham, D., d'Ozouville, N. \& Harpp, K.) (AGU, Washington, DC, 2014). In press.

24. Bryce, J. G., DePaolo, D. J. \& Lassiter, J. C. Geochemical structure of the Hawaiian plume: $\mathrm{Sr}, \mathrm{Nd}$, and Os isotopes in the $2.8 \mathrm{~km}$ HSDP-2 section of Mauna Kea volcano. Geochem. Geophys. Geosyst. 6, Q09G18 (2005).

25. Coltice, N., Moreira, M., Hernlund, J., Labrosse, S. Crystallization of a basal magma ocean recorded by helium and neon. Earth Planet. Sci. Lett. 308, 193-199 (2011).

26. Mukhopadhyay, S. Early differentiation and volatile accretion recorded in deep- 
mantle neon and xenon. Nature 486, 101-104 (2012).

27. Li., M., McNamara, A.K., Garnero, E.J. Chemical complexity of hotspots caused by cycling oceanic crust through mantle reservoirs. Nature Geoscience (2014). Published online. doi:10.1038/ngeo2120

28. Natland, J. H. The progression of volcanism in the Samoan linear volcanic chain. Am. J. Sci. 280A, 709-735 (1980).

29. Hart, S.R., Coetzee, M., Workman, R. K., Blusztajn, J., Johnson, K. T. M., Sinton, J., Steinberger, B., \& Hawkins, J.W. Genesis of the Western Samoa (WESAM) seamount province: Age, geochemical fingerprint and tectonics. Earth Planet. Sci. Lett. 227, 3756 (2004).

30. Eisele, J., Abouchami, W., Galer, S.J.G., \& Hofmann, A.W. The 320 kyr Pb isotope evolution of Mauna Kea lavas recorded in the HSDP-2 drill core. Geochem., Geophys., Geosyst., 4 (2003). doi:10.1029/2002GC000339

Supplementary Information accompanies the paper on www.nature.com/nature.

Acknowledgements. We thank Jim Natland and Marcel Regelous for discussion, and R. Carlson for access to analytical facilities. Comments from Barry Hanan, Karen Harpp and an anonymous reviewer improved the manuscript. Jackson acknowledges grants from NSF that funded this research: OCE-1061134, OCE1153894, EAR-1348082 and EAR-1145202.

Author Contributions. M.J. conceived of the project, performed most of the $\mathrm{Sr}, \mathrm{Nd}$ and $\mathrm{Pb}$ isotopic analyses, and wrote the paper. S.H. provided analytical access and insights into the nature of the Samoan mantle. J.K. performed statistical modeling, improved figures, and added discussion about the volcanic stages during the evolution of a Samoan volcano. M.K. performed helium isotopic measurements, K.F. 
performed helium isotopic measurements and some $\mathrm{Sr}$ and $\mathrm{Nd}$ isotopic measurements, and J.B. helped with sample preparation and made several $\mathrm{Sr}$ and $\mathrm{Pb}$ isotopic measurements. All authors contributed intellectually to the manuscript.

Author Information. Reprints and permissions information is available at www.nature.com/reprints. The authors declare no competing financial interests. Correspondence and requests for materials should be addressed to M.G.J. (jackson@geol.ucsb.edu).

\section{Figure Legends}

Figure 1. Map of the Samoan hotspot showing the division of the hotspot into three parallel volcanic lineaments. The volcanic lineaments define three geochemical groups, and the colors of the data symbols in the isotopic plots indicate the volcanic lineament from which a sample was taken. Rejuvenated lavas (turquoise shaded areas) overlie shield-stage lavas on Tutuila and Upolu, but rejuvenated volcanism on Savai'i is extensive and all earlier stages have been completely covered ${ }^{21}$. However, ref. 28 infers that, like Upolu and Tutuila, shield stage volcanism similar to the subaerial Upo-lineament lavas (called 'Fagaloa series') underlies the extensive rejuvenated volcanism on Savai'i. The map is modified after ref. 21. Alexa seamount is located $\sim 1200 \mathrm{~km}$ west of Sava'i ${ }^{29}$.

Figure 2. Pb-isotopic plot showing the isotopic separation of the volcanic lineaments in Samoa and the convergence of the four geochemical groups on the high ${ }^{3} \mathrm{He} /{ }^{4} \mathrm{He}$ component region. The colors for each data group are based on the geographic lineament where the samples were taken. Samples for which $\mathrm{Pb}$-isotopic ratios were measured by high-precision techniques (Pb-spiked samples run by TIMS and samples run 
using TI-addition by MC-ICP-MS) are shown as large symbols (where estimated external uncertainties are smaller than the symbols). Unspiked Pbisotopic TIMS data are shown as small symbols (where estimated $2 \sigma$ external uncertainties are better than $\pm 0.019, \pm 0.023$ and \pm 0.076 for ${ }^{206} \mathrm{~Pb} /{ }^{204} \mathrm{~Pb}$, ${ }^{207} \mathrm{~Pb} /{ }^{204} \mathrm{~Pb}$ and ${ }^{208} \mathrm{~Pb} /{ }^{204} \mathrm{~Pb}$, respectively; see Methods); example $2 \sigma$ external uncertainties for unspiked $\mathrm{Pb}$-isotopic TIMS data are shown in the figure. Subaerial Upo-lineament lavas trend toward a depleted component not unlike that found in MORB or Hawaiian lavas from the HSDP-2 (Hawaiian Scientific Drilling Program-II) drill core ${ }^{30}$; Alexa $^{29}$ is a volcano in the western Samoan region that anchors the DM isotopic group in the Samoan suite (Methods). The submarine lavas from the western region of the hotspot-dredged off the coast of Savai'i and from Tisa seamount-are excluded from the statistical treatment; while the lavas from the submarine portion of the western Samoan islands are shown with the same symbol, this does not imply that they are related by a common process or part of the same volcanic lineament. Vailineament lavas host a dilute HIMU component ${ }^{17}$, Malu-lineament lavas host an EM2 component ${ }^{17}$, and rejuvenated lavas sample an EM1 component ${ }^{21}$. The high ${ }^{3} \mathrm{He} /{ }^{4} \mathrm{He}$ common component region (grey ellipse) defines the $2 \sigma$ variance around the average in the $\mathrm{Pb}$-isotopic compositions for samples with ${ }^{3} \mathrm{He} /{ }^{4} \mathrm{He}>20 \mathrm{Ra}$; the colored fields represent $99 \%$ confidence intervals around the best-fit lines through each data group (see Methods). See Supplementary Table 4 for a compilation of the Samoan data shown. 
Figure 3. Relationship between $\mathrm{He}$ and $\mathrm{Pb}$ isotopic ratios in Samoan lavas. ${ }^{3} \mathrm{He} /{ }^{4} \mathrm{He}$ is plotted versus $\mathrm{DPb}_{6-7-8}$, which represents distance from the common component region in $\mathrm{Pb}$-isotopic space (as defined in the Methods), and shows that ${ }^{3} \mathrm{He} /{ }^{4} \mathrm{He}$ decreases in samples moving away from the common component region. Samples with $<10^{-9} \mathrm{cc} \mathrm{STP} / \mathrm{g}{ }^{4} \mathrm{He}$ are excluded. The different isotopic groups do not overlap perfectly, suggesting that the different endmembers have different $\mathrm{He} / \mathrm{Pb}$ ratios. Errors for helium measurements are smaller than the data symbols. Symbols are the same as Figure 2. See Supplementary Table 4 for a compilation of the Samoan data shown.

Figure 4. Conceptual model of the geochemical geometry of the Samoan plume, as sampled by shield-stage lavas, and how it relates to the geochemical distinction among the parallel volcanic lineaments. Two snapshots of the Samoan plume and the associated shield volcanism are shown: 1.) during Upo-lineament volcanism at $\sim 2 \mathrm{Ma}$ (left) and, 2.) present-day construction of the Vai and Malu lineaments (right). The volcanic lineaments in the time snapshot on the right mimic the map in Figure 1. Colors of the volcanic lineaments and related mantle components in the plume correspond to the colors in the legend in Figure 2.

\section{METHODS}

New Sr, Nd, Pb and He measurements. The new Pb-isotopic analyses were performed at DTM (Department of Terrestrial Magnetism) and WHOI (Woods Hole Oceanographic 
Institution). Pb chemistry at DTM employs a double column pass and follows the method outlined in ref. $31 . \mathrm{Pb}$ chemistry at WHOI consists of a single column pass and follows the $\mathrm{HBr}-\mathrm{HNO}_{3}$ procedure of ref. 32 and ref. 33 .

As described in Supplementary Table 1, $\mathrm{Pb}$ isotopic compositions for a subset of the Samoan lavas were measured on the VG-P54 MC-ICP-MS at DTM in February 2009. Refer to ref. 34 for methods of $\mathrm{Pb}$-isotopic measurement. Thallium was added as an internal isotopic standard to correct for instrumental mass fractionation. All measurements were made during a single day-long analytical session, during which time 8 separate runs of the NIST 981 standard were made, and the reproducibility of the 8 measurements was $840 \mathrm{ppm}, 820 \mathrm{ppm}$ and $800 \mathrm{ppm}$ for the ${ }^{206} \mathrm{~Pb} /{ }^{204} \mathrm{~Pb},{ }^{207} \mathrm{~Pb} /{ }^{204} \mathrm{~Pb}$ and the ${ }^{208} \mathrm{~Pb} /{ }^{204} \mathrm{~Pb}$ ratios $(2 \sigma$, standard deviation of the mean). The Pb-isotopic data on basaltic samples run during this analytical session were normalized to the average value determined by the 981 analyses that bracket the basaltic analyses over the analytical session. The data were normalized to the NIST 981 values reported by ref. 35 : ${ }^{206} \mathrm{~Pb} /{ }^{204} \mathrm{~Pb}=16.9356,{ }^{207} \mathrm{~Pb} /{ }^{204} \mathrm{~Pb}=15.4891$, and ${ }^{208} \mathrm{~Pb} /{ }^{204} \mathrm{~Pb}=36.7006$.

The remaining $\mathrm{Pb}$-isotopic measurements reported in Supplementary Table 1 were made on the Neptune multicollector ICP-MS at WHOI over six separate analytical sessions from November 2003 to October 2008. Note that many of the samples measured for $\mathrm{Pb}$ isotopes at WHOI were previously measured by lower-precision TIMS methods (i.e., unspiked analyses), and we report new, higher precision analyses here. Again, a Tl internal standard was used to correct for instrumental mass fractionation. The long-term external reproducibility on NIST 981 standard runs at WHOI is $<120 \mathrm{ppm}$ for the ${ }^{206} \mathrm{~Pb} /{ }^{204} \mathrm{~Pb},{ }^{207} \mathrm{~Pb} /{ }^{204} \mathrm{~Pb}$ and ${ }^{208} \mathrm{~Pb} /{ }^{204} \mathrm{~Pb}$ ratios ${ }^{29,36}$. After normalization of the basaltic 
sample runs to the average NIST 981 value measured in a given analytical session, the data were then normalized to the NIST 981 values reported by ref. 35 .

Supplementary Table 2 includes new ${ }^{87} \mathrm{Sr} /{ }^{86} \mathrm{Sr}$ and ${ }^{143} \mathrm{Nd} /{ }^{144} \mathrm{Nd}$ isotopic measurements. Analyses made at WHOI follow chemical separation techniques outlined in ref. 29; $\mathrm{Sr}$ and $\mathrm{Nd}$ isotopic measurements were made on the Neptune multicollector ICP-MS at WHOI, and standard normalization and long-term external precision are described in ref. 29. The $\mathrm{Sr}$ and $\mathrm{Nd}$ isotopic analyses made at SIO (Scripps Institution of Oceanography) follow analytical techniques outlined in ref. 14.

Supplementary Table 3 includes new helium isotopic measurements, which were measured at WHOI and at SIO. Measurements made at WHOI follow the methods outlined in ref. 37. All data were obtained by crushing olivines or glasses in vacuum, except for one sample, which is a measurement of gas released by fusion following a crushing experiment. In-run precision is reported in the Table. Measurements made at SIO follow the methods outlined in ref. 14 , where uncertainty in ${ }^{3} \mathrm{He} /{ }^{4} \mathrm{He}$ ratios is estimated to be $\pm 0.5 \mathrm{Ra}$.

Calculating distance in 3-dimensional Pb-isotopic space. The expression for distance in $\mathrm{Pb}$ multi-isotopic space, here called $\mathrm{DPb}_{6-7-8}$, is given by the following relationship:

$$
\left.\mathrm{DPb}_{6-7-8}=\left[\left({ }^{206} \mathrm{~Pb}^{204} \mathrm{~Pb}_{\mathrm{s}^{-}}{ }^{206} \mathrm{~Pb} /{ }^{204} \mathrm{~Pb}_{\mathrm{R}}\right) / \mathrm{X}\right)^{2}+\left(\left({ }^{207} \mathrm{~Pb} /{ }^{204} \mathrm{~Pb}_{\mathrm{s}^{-}}{ }^{207} \mathrm{~Pb}^{204} \mathrm{~Pb}_{\mathrm{R}}\right) / \mathrm{Y}\right)^{2}+\left(\left({ }^{208} \mathrm{~Pb}^{204} \mathrm{~Pb}_{\mathrm{s}^{-}}{ }^{208} \mathrm{~Pb} /{ }^{204} \mathrm{~Pb} \mathrm{R}\right) / \mathrm{Z}\right)^{2}\right]^{0.5}
$$

Where the subscript $\mathrm{R}$ indicates the isotopic composition of the reference sample, the subscript $\mathrm{S}$ is the isotopic composition of a Samoan lava, and $\mathrm{X}, \mathrm{Y}$ and $\mathrm{Z}$ represent the 
absolute difference between the maximum and minimum values measured in Samoan hotspot lavas (including rejuvenated lavas and all lavas from the Vai, Malu and Upolineaments) for the ${ }^{206} \mathrm{~Pb} /{ }^{204} \mathrm{~Pb}(\mathrm{X}=19.4993-18.5720=0.9273),{ }^{207} \mathrm{~Pb} /{ }^{204} \mathrm{~Pb}(\mathrm{Y}=$ $15.6510-15.5538=0.0972)$ and ${ }^{208} \mathrm{~Pb} /{ }^{204} \mathrm{~Pb}(\mathrm{Z}=39.8620-38.6929=1.1691)$ ratios, respectively. The reference isotopic composition is chosen to be the highest ${ }^{3} \mathrm{He} /{ }^{4} \mathrm{He}$ lava from Samoa (Ofu-04-06) ${ }^{20}$, which plots near the region of convergence of the four isotopic groups.

The expression for distance $\left(\mathrm{DPb}_{6-7-8}\right)$ in $\mathrm{Pb}$-isotopic space is based on the Pythagorean theorem, where the differences between each $\mathrm{Pb}$-isotopic ratio and the common component are squared, these squared differences are then summed, and the square root of the sum is taken. The expression for distance in $\mathrm{Pb}$-isotopic space (i.e., $\left.\mathrm{DPb}_{6-7-8}\right)$ also accounts for the fact that different $\mathrm{Pb}$-isotopic ratios exhibit dramatically different variability. In order to do this, the difference in the $\mathrm{Pb}$-isotopic ratio between two data points is divided by the total range measured in Samoan lavas. For example, the total range in ${ }^{206} \mathrm{~Pb} /{ }^{204} \mathrm{~Pb}$ in Samoan lavas is 0.9273 , which is the difference between the highest measured ${ }^{206} \mathrm{~Pb} /{ }^{204} \mathrm{~Pb}$ ratio [19.4993] and the lowest ratio [18.5720]). Thus, the ${ }^{206} \mathrm{~Pb} /{ }^{204} \mathrm{~Pb}$ ratio exhibits $5.0 \%$ variability in Samoan lavas. This is important because, in Samoan lavas, ${ }^{208} \mathrm{~Pb} /{ }^{204} \mathrm{~Pb}$ varies from 39.8620 to 38.6929 in Samoa, which represents $\sim 3.0 \%$ variability, while ${ }^{207} \mathrm{~Pb} /{ }^{204} \mathrm{~Pb}$ exhibits only $0.6 \%$ variability (15.6510 to 15.5538 in Samoan lavas). If the distance equation did not normalize the isotopic difference between data points by the total range in the isotopic ratio of interest, then the distances calculated would be dominated by the ${ }^{206} \mathrm{~Pb} /{ }^{204} \mathrm{~Pb}$ and ${ }^{208} \mathrm{~Pb} /{ }^{204} \mathrm{~Pb}$ variability, and ${ }^{207} \mathrm{~Pb} /{ }^{204} \mathrm{~Pb}$ (which 
has limited variability in Samoa and in the OIB mantle in general) would contribute very little to the overall distance calculated.

We emphasize that the different isotopic groups converge on a common "region" rather than a point in $\mathrm{Pb}$-isotopic space. No single sample in the existing Samoan dataset, including Ofu-04-06, is ideally suited as a point of convergence for all the geochemical groups in Samoa. However, given the limited available dataset on high ${ }^{3} \mathrm{He} /{ }^{4} \mathrm{He}$ Samoan lavas, and given the observation that Ofu-04-06 plots near the the region of convergence of the different isotopic groups, we choose the isotopic composition of this lava as a reference isotopic composition in the $\mathrm{DPb}_{6-7-8}$ equation because it has the highest ${ }^{3} \mathrm{He} /{ }^{4} \mathrm{He}$.

\section{Statistical test for the convergence of the four Pb-isotopic groups on the high} ${ }^{3} \mathrm{He} /{ }^{4} \mathrm{He}$ component. The relationship between ${ }^{3} \mathrm{He} /{ }^{4} \mathrm{He}$ and distance from the common component region in $\mathrm{Pb}$-isotopic space- where ${ }^{3} \mathrm{He} /{ }^{4} \mathrm{He}$ decreases with increasing distance (higher $\mathrm{DPb}_{6-7-8}$ values) from the common component region - is consistent with a model where the four low ${ }^{3} \mathrm{He} /{ }^{4} \mathrm{He}$ components in the Samoan plume mix with a common high ${ }^{3} \mathrm{He} /{ }^{4} \mathrm{He}$ component. In order to evaluate whether the four different isotopic groups - represented by lavas from the Malu, Vai and subaerial-Upo lineaments and rejuvenated lavas (Extended Data Figure 1)—converge on the high ${ }^{3} \mathrm{He} /{ }^{4} \mathrm{He}$ common component region in $\mathrm{Pb}$-isotopic space, we first define the high ${ }^{3} \mathrm{He} /{ }^{4} \mathrm{He}$ common component region to be comprised of all Samoan lavas with ${ }^{3} \mathrm{He} /{ }^{4} \mathrm{He}>20 \mathrm{Ra}$. Since many samples measured for $\mathrm{Pb}$ isotopes were not suitable for ${ }^{3} \mathrm{He} /{ }^{4} \mathrm{He}$ measurements, this allows us to compensate for potential under-sampling of the high ${ }^{3} \mathrm{He} /{ }^{4} \mathrm{He}$ common component and to define uncertainty in the composition of the common component. We 
model the compositional range of the common component region with the mean and the variance of the $\mathrm{Pb}$-isotope data (and Nd-isotopic data) for samples with ${ }^{3} \mathrm{He} /{ }^{4} \mathrm{He}>20 \mathrm{Ra}$ (see Figure 2 and Extended Data Figures 2 and 3). This results in an ellipsoid centered on the mean value and with major axes defined by the $2 \sigma$ variations in the heavy radiogenic isotopic compositions. Subsequently, we test whether the four data groups indeed converge on this ellipsoidal common component region, taking advantage of the linearity of mixing relationships in $\mathrm{Pb}$-isotopic space. In order to model the possible orientations of mixing lines for each group, we use best-fit trends through each group and their related confidence intervals. We computed Working-Hotelling confidence intervals at the $99 \%$ confidence level to be as inclusive as possible in visualizing possible mixing lines for each group (we tested 95\% confidence as well, and the conclusions are the same). In three-dimensional $\mathrm{Pb}$-isotopic space, the $99 \%$ confidence intervals (they appear as "tubes" in three-dimensional isotopic space; Figure 2 and Extended Data Figures 2 and 3) around each of the best-fit trend lines overlap with the ellipsoid that encompasses the common component region that is defined by the highest ${ }^{3} \mathrm{He} /{ }^{4} \mathrm{He}$ lavas. This observation shows that, for each data group, there exists a family of mixing lines (within error of the best-fit line) that statistically overlaps with our common component region. This isotopic overlap also maps to two-dimensional Pb-isotopic spaces (see Figure 2 and Extended Data Figure 3), although the three-dimensional case shows that only a subset of possibilities in individual two-dimensional plots is actually possible. In summary, all four of the best-fit trend lines through the four different isotopic groups statistically overlap with the common component region in $\mathrm{Pb}$-isotopic space. 
However, we note that submarine lavas from western Samoan (i.e., lavas dredged off the coast of Sava'i and Upolu) are excluded from this statistical test. Available data from these lavas do suggest that they follow the relationship between ${ }^{3} \mathrm{He} /{ }^{4} \mathrm{He}$ and distance from the common component region in $\mathrm{Pb}$-isotopic space (Figure 2), which is consistent with mixing with the common component region. However, the limited sampling of the submarine portion of the western Samoan region makes it difficult to assign the few available samples to geographic groups: For example, only Savai'i (4 dredges: ALIA114, ALIA115, ALIA116 and ALIA128) and Tisa seamount (1 dredge; ALIA113) have samples of the deep submarine portions of the western Samoan region, and several of the dredges are distal to the Upo volcanic lineament. Thus, the vast submarine region in western Samoa, which spans $200 \mathrm{~km}$ (from eastern Savai'i to Tisa), is represented by only 5 submarine dredges, and several dredges distal to Savai'i and Upolu and do not clearly belong to the Upo-lineament (indeed, the distance between the northernmost and southernmost dredges in the western Samoa region is $>130 \mathrm{~km}$, which is more than twice the distance that separates the Vai and Malu volcanic lineaments). Our statistical approach requires that the Samoan data are grouped along geographic trends, and we test whether these geographically-defined data groups converge on the high ${ }^{3} \mathrm{He} /{ }^{4} \mathrm{He}$ component region in isotopic space. With such poor sampling along the submarine portion of the western Samoan islands, and the improbability that these dredges sample the same geographic lineament, it is not yet possible to evaluate geographic groups in the isotopic datasets in the submarine portion of the western Samoan region. 
Geographic separation of the isotopic components in Samoa. The geographic-isotopic groups (the Vai, Malu and Upo volcanic lineaments and rejuvenated lavas) are resolved in multiple isotopic spaces (Figure 2, Extended Data Figures 2 and 3). Below, we describe the seamounts and islands that comprise the four geographic groups that are resolved in isotopic space:

i. Vai lineament: The Vai volcanic lineament is comprised of the islands of Ofu and Ta'u, and Vailulu'u, Soso, Tamai'i and Muli seamounts. In isotopic space, including ${ }^{206} \mathrm{~Pb} /{ }^{204} \mathrm{~Pb}$ vs ${ }^{208} \mathrm{~Pb} /{ }^{204} \mathrm{~Pb},{ }^{206} \mathrm{~Pb} /{ }^{204} \mathrm{~Pb}$ vs ${ }^{207} \mathrm{~Pb} /{ }^{204} \mathrm{~Pb}$ and ${ }^{206} \mathrm{~Pb} /{ }^{204} \mathrm{~Pb}$ vs ${ }^{143} \mathrm{Nd} /{ }^{144} \mathrm{Nd}$, some of the Vailulu'u lavas trend slightly outside of the data group formed by other Vailineament volcanoes. These anomalous lavas trend in the direction of Malu-lineament lavas in isotopic space, indicating that Vailulu'u samples components similar to that found in the mantle sources of both the Vai and Malu volcanic lineaments, but lavas from the Vai-lineament rarely sample the component hosted along the Malu volcanic lineament. Two Vailulu'u samples from the same dredge-AVON3-73-1 and AVON-373-12 - plot squarely in the field defined by Malu-lineament lavas, and show that, like the Hawaiian Loa and Kea volcanic lineaments ${ }^{4,5}$, the isotopic separation of the Malu and Vai volcanic lineaments is not perfect. Another lava from the Vai volcanic lineament, Ta'u sample T44, plots closer in isotopic space to lavas that comprise the Malu volcanic lineament. Ta'u sample T14, which exhibits highly unradiogenic $\mathrm{Pb}$ and anomalous $\mathrm{Pb}$ concentrations relative to other Ta'u lavas ${ }^{17}$, may be contaminated and is not shown here.

ii. Malu lineament: The Malu volcanic lineament is geographically displaced to the south of the Vai volcanic lineament and is comprised of the Malumalu, Malutut and Tulaga seamounts and the Masefau shield lavas of northeast Tutuila. We find that three 
Malu-lineament lavas from dredges 108 (DR108) and 109 (DR109) from the ALIA cruise $^{18,19,38,39}$ have Vai lineament-like geochemistry, again showing that the geochemical distinction between the two parallel volcanic ridges is not perfectly resolved in isotopic space.

The Malu volcanic lineament joins seamlessly with the northeast region of the island of Tutuila. Tutuila lavas with geochemistry similar to Malu-lineament lavas, referred to as Masefau shield lavas ${ }^{14}$, outcrop only along the north coast of the northeastern region of the island along the Afono, Maefau and Sailele Bays (Natland, 2013 pers. comm.). Masefau lavas have not been encountered anywhere else on Tutuila, with the possible exception of sample 91-TP-252, which was collected on the southern coast of the northeast portion of the island (however, this sample is a cobble, so its true provenance is unknown). Less geochemically-enriched Tutuila lavas, referred to as Pago shield lavas ${ }^{14,40}$, outcrop on the rest of the island. Using radiometric age data from ref. 41 , lavas identified geochemically as Pago shield lavas in the western region of the island are generally younger than lavas identified as Masefau shield lavas on the eastern side of the island (see ref. 41 and references therein). Indeed, the Masefau shield sequences are cross-cut by dikes with Pago shield geochemical signatures ${ }^{14}$. Work pairing geochemistry with age data is relatively scarce in Samoa, and further work is needed to evaluate the temporal relationship between the Masefau and Pago shield series. However, based on existing data, we argue that Tutuila is divided between two volcanic series, and the younger Pago shield series overlies much of the older Masefau series, much like the Hawaiian Mauna Loa series overlies the Mauna Kea series in the HSDP2 drill core ${ }^{42}$ (we note that these two volcanoes, Mauna Kea and Mauna Loa, sample the separate volcanic 
lineaments along the Hawaiian hotspot, just as the Pago and Masefau shield sample two separate volcanic lineaments in Samoa). We further argue that the two volcanic series on Tutuila anchor the Upo and Malu volcanic lineaments, both geochemically and geographically. The Malu volcanic lineament joins with the northeastern region of Tutuila where the isotopically-related Masefau lavas are encountered, and we argue that Tutuila Masefau lavas anchor the westernmost portion of the Malu lineament (and the Tutuila Pago lavas anchor the easternmost limb of the Upo volcanic lineament, see below).

iii. Upo lineament: Pago shield lavas from Tutuila are isotopically similar to subaerial Upolu shield lavas (subaerial Upo-lineament lavas from Upolu have previously been referred to at Fagaloa shield lavas) ${ }^{40,43}$, and they outcrop on the western and southern portions of Tutuila (and as dikes cross-cutting the Masefau shield lavas in northeast Tutuila). We argue that the Pago shield lavas mark the easternmost extent of the Upo volcanic lineament, while Tutuila Masefau lavas define the westernmost extent of the Malu volcanic lineament. Thus, Tutuila Island acts as a nexus between the Upo lineament (Pago shield series on southern Tutuila) and the Malu lineament (Masefau shield series on northern Tutuila). In contrast to all other volcanic structures in Samoa, which strike along a direction parallel to absolute plate motion (WNW-ESE), the island of Tutuila is oriented obliquely to plate motion (WSW-ENE) ${ }^{41}$. Thus, the Malu lineament "steps off" to the northeast, away from the Upo lineament, and Tutuila effectively bridges these two volcanic lineaments.

Shield lavas from Upolu have similar isotopic compositions to Pago shield lavas on Tutuila (Figure 2, Extended Data Figure 3), and the Upo volcanic lineament is 
comprised of lavas from at least two islands. Fagaloa series lavas that define the subaerial Upo-lineament also may exist on Savai'i, but if they do, they have been completely covered with young rejuvenated lavas ${ }^{28}$.

The volcanic stage suggested for two subaerial Upolu lavas may require new designation based on their geochemical characteristics. Upolu samples U30L and U10S (see ref. 17) were tentatively classified in the field as rejuvenated-stage lavas on the basis of a geological map from ref. 43. Later isotopic analyses ${ }^{17}$ showed that these two samples plot in the field of shield lavas (M. Regelous, pers. comm., 2013), and we argue that these two samples belong to the shield stage. We note that $\mathrm{Pb}$-isotopic data reported on Tutuila lavas from the Pago shield (and Upolu lavas) by ref. 44 are severely contaminated and are excluded from the present study ${ }^{45}$.

iv. Rejuvenated lava lineament: The Samoan islands of Savai'i, Upolu and Tutuila have variable extents of rejuvenated lava cover, from only minor rejuvenated volcanism cover on Tutuila to near-complete cover of the shield stage by rejuvenated lavas on Savai' ${ }^{21}$. In radiogenic isotopic spaces, the rejuvenated lavas form a separate field that is resolved from shield-stage lavas, and the rejuvenated lavas from each island are isotopically similar (Figure 2, Extended Data Figure 3). The origin of Samoan rejuvenated lavaswhich are volumetrically extensive - is not well understood, but is thought to at least partially relate to tectonically-enhanced melting that owes to tectonic stresses in the region generated by the nearby Tonga trench ${ }^{17,21,28,29,40,46}$.

Geochemical identity of the 5 mantle components in the Samoan plume. The identity of the four low ${ }^{3} \mathrm{He} /{ }^{4} \mathrm{He}$ mantle species in the Vai- and Malu-lineaments, the subaerial 
Upo-lineament and rejuvenated lavas can be determined by examining their geochemical characteristics. Below we argue that the four low ${ }^{3} \mathrm{He} /{ }^{4} \mathrm{He}$ components in the Samoan plume sample the canonical mantle endmembers-EM1, EM2, HIMU and DM—in variably diluted forms. A fifth component, which is characterized by having high ${ }^{3} \mathrm{He} /{ }^{4} \mathrm{He}$, has telltale geochemical signatures that give clues to its origin:

i. Malu-lineament: Malu lineament lavas have geochemical signatures associated with the EM2 mantle endmember, including negative $\mathrm{Ti}$ (and $\mathrm{Nb}$, not shown) anomalies (Extended Data Figure 4), and very high ${ }^{87} \mathrm{Sr} /{ }^{86} \mathrm{Sr}$ (refs. 17 and 19). The earliest shieldstage lavas on Savai'i, dredged on the deep submarine flanks of Savai'i $(4.8 \text { to } 5.3 \mathrm{Ma})^{18}$, have isotopic and trace element signatures of an even more extreme EM2 component (with ${ }^{87} \mathrm{Sr} /{ }^{86} \mathrm{Sr}$ up to 0.7216 ) ${ }^{19}$ that complements the EM2 signature that characterizes Malu-lineament volcanics ${ }^{14,17,47,48}$. The EM2 component in Samoa is best modelled by recycling subducted, continentally-derived sediment into the Samoan mantle $\mathrm{e}^{19,47-49}$.

ii. Vai-lineament. Vai-lineament lavas have geochemical signatures that are similar to the HIMU mantle endmember (albeit in greatly diluted form). Vai-lineament lavas have the highest $(\mathrm{U}+\mathrm{Th}) / \mathrm{Pb}$ (Extended Data Figure 5) and the most radiogenic ${ }^{206} \mathrm{~Pb} /{ }^{204} \mathrm{~Pb}$ (Figure 2, Extended Data Figure 3) in the Samoan suite. High $(\mathrm{Th}+\mathrm{U}) / \mathrm{Pb}$ is a a characteristic of HIMU lavas ${ }^{50}$. Clearly, Vai-lineament lavas do not exhibit the highly radiogenic $\mathrm{Pb}$-isotopic compositions evident in HIMU end-member locations like Mangaia and Tubuai (e.g., ref. 51), but we argue that Vai-lineament lavas host a dilute HIMU component that is not sampled in pure end-member form in Samoa, at least in lavas studied to-date. The most extreme HIMU components in the mantle have been linked to ancient recycled oceanic crust (e.g., refs 51-54). 
iii. Upo-lineament. Subaerial lavas from the Upo volcanic lineament trend toward a depleted mantle compostion in various isotopic spaces (Figure 2, Extended Data Figures 3 and 4), and are characterized by the highest ${ }^{143} \mathrm{Nd} /{ }^{144} \mathrm{Nd}$ in the Samoan suite. Supporting this hypothesis, ${ }^{143} \mathrm{Nd} /{ }^{144} \mathrm{Nd}$ increases along the subaerial Upo-lineament group moving away from the high ${ }^{3} \mathrm{He} /{ }^{4} \mathrm{He}$ common component region (as $\mathrm{DPb} 6$ 6-7-8 increases) in the direction of MORB and Hawaiian lavas from the HSDP-2 drill core (Figure 2, Extended Data Figure 4). By comparison, the other three data groups exhibit relatively constant or even decreasing ${ }^{143} \mathrm{Nd} /{ }^{144} \mathrm{Nd}$ with increasing distance from the high ${ }^{3} \mathrm{He} /{ }^{4} \mathrm{He}$ common component region. (Curiously, ${ }^{143} \mathrm{Nd} /{ }^{144} \mathrm{Nd}$ exhibits the least amount of variability in the high ${ }^{3} \mathrm{He} /{ }^{4} \mathrm{He}$ common component region — where $\mathrm{DPb}_{6-7-8}$ is near zero-as the common component region has relatively homogeneous isotopic characteristics.) Thus, subaerial lavas from the Upo-lineament group appear to sample a depleted mantle composition, a hypothesis that is supported by the observation that average $\mathrm{MORB}^{55}$ and Hawaii Kea lavas (which exhibit geochemically depleted ${ }^{143} \mathrm{Nd} /{ }^{144} \mathrm{Nd}$ ) anchor the data trends for Upolu shield and Tutuila Pago lavas in all isotopic spaces $^{17}$. The western Samoan seamount Alexa ${ }^{29}$ anchors the most extreme terminus of the Samoan DM isotopic group sampled by subaerial Upo-lineament lavas, and data from this seamount are shown in all relevant isotopic spaces and the data plot near the field for Hawaiian Kea lavas. Thus, the geochemical component sampled by Upo-lineament lavas is not unlike the depleted plume component sampled by Hawaiian Kea lavas, and may be inherent to the Samoan plume, but we cannot exclude a depleted upper mantle source (like that which sources MORB) as the endmember sampled by Upo-lineament lavas. 
iv. Rejuvenated lavas. Rejuvenated lavas from Samoa exhibit a mild EM1 component, and this is supported by positive Ba-anomalies (high $\mathrm{Ba} / \mathrm{Th}$ in Supp Figure 4) in Samoan rejuvenated lavas ${ }^{17,29,38}$, a geochemical characteristic shared with EM1 end-member lavas from Pitcairn ${ }^{29}$. Relative to Samoan shield lavas, Samoan rejuvenated lavas exhibit elevated ${ }^{208} \mathrm{~Pb} /{ }^{204} \mathrm{~Pb}$ at a given ${ }^{206} \mathrm{~Pb} /{ }^{204} \mathrm{~Pb}$, a characteristic that is also shared with EM1flavored lavas globally.

v. High ${ }^{3} \mathrm{He}{ }^{A} \mathrm{He}$ component: The variably diluted mantle endmembers identified in Samoan lavas-EM2, EM1, HIMU and DM - are known to have relatively low ${ }^{3} \mathrm{He} /{ }^{4} \mathrm{He}$ 17,19,56-59. These low ${ }^{3} \mathrm{He} /{ }^{4} \mathrm{He}$ components anchor the four isotopic groups in the region of isotopic space furthest from the high ${ }^{3} \mathrm{He} /{ }^{4} \mathrm{He}$ common component region. However, lavas with relatively high to very high ${ }^{3} \mathrm{He} /{ }^{4} \mathrm{He}$ are found on several islands and seamounts (up to 33.4 Ra on Ofu, 18.0 Ra on Ta'u, 25.8 Ra on Tutuila, 19.3 Ra on Upolu, 15.9 Ra on Malumalu, 15.3 Ra on Muli, and 18.6 Ra on Savai'i), and these lavas tend to plot near the high ${ }^{3} \mathrm{He} /{ }^{4} \mathrm{He}$ common component region (Figure 3; Extended Data Figure 6). High ${ }^{3} \mathrm{He} /{ }^{4} \mathrm{He}$ lavas in Samoa have uniquely high $\mathrm{Ti} / \mathrm{Ti}^{*}$ values ${ }^{60,61}$ (in contrast to the low $\mathrm{Ti} / \mathrm{Ti}^{*}$ observed in the Samoan EM2 endmember; Extended Data Figure 4). Consistent with this observation, $\mathrm{Ti} / \mathrm{Ti}^{*}$ is highest near the high ${ }^{3} \mathrm{He} /{ }^{4} \mathrm{He}$ common component region; moving away from the center of the common component region (from high to low $\mathrm{DPb}_{6-7-8}$ values), $\mathrm{Ti} / \mathrm{Ti}^{*}$ decreases in the direction of the four low ${ }^{3} \mathrm{He} /{ }^{4} \mathrm{He}$ endmembers (Extended Data Figure 4). This unique relationship between $\mathrm{Ti} / \mathrm{Ti}^{*}$ and ${ }^{3} \mathrm{He} /{ }^{4} \mathrm{He}$ is highlighed by the elevated $\mathrm{Ti} / \mathrm{Ti} *$ observed in high ${ }^{3} \mathrm{He} /{ }^{4} \mathrm{He}$ lavas globally ${ }^{60}$.

Samoan lavas with high ${ }^{3} \mathrm{He} /{ }^{4} \mathrm{He}$ are melts of a mantle component with a controversial origin, and these lavas cluster in the common component region in isotopic 
space (Extended Data Figure 6). Ref. 14 argued that the high ${ }^{3} \mathrm{He} /{ }^{4} \mathrm{He}$ Samoan component represents primitive, undegassed mantle, and referred to this component PHEM (Primitive Helium Mantle). However, higher ${ }^{3} \mathrm{He} /{ }^{4} \mathrm{He}$ ratios (up to $33.4 \mathrm{Ra}$ ) identified in Samoan lavas have ${ }^{143} \mathrm{Nd} /{ }^{144} \mathrm{Nd}$ that are geochemically depleted relative to primitive, chondritic material, and $\mathrm{Pb}$-isotopic compositions that are far from the geochron ${ }^{20}$. Nonetheless, high ${ }^{3} \mathrm{He} /{ }^{4} \mathrm{He}$ Samoan lavas have lower (geochemically more enriched) ${ }^{143} \mathrm{Nd} /{ }^{144} \mathrm{Nd}$ than lavas with high ${ }^{3} \mathrm{He} /{ }^{4} \mathrm{He}$ from other hotspots ${ }^{20}$, and it was suggested that relatively young ( $\sim 10 \mathrm{Ma})$ sediments rapidly-cycled from the Tonga trench might account for this Nd-isotopic shift ${ }^{62,63}$. However, the Pb-isotopic compositions in Samoan lavas preclude the existence of a young sediment component in the Samoan mantle ${ }^{19}$, and sediments from the Tonga trench in particular are a poor fit for Samoan lavas in Pb-isotopic space (see Figure 3 in ref. 20). The origin of the enriched geochemical signatures in Samoan high ${ }^{3} \mathrm{He} /{ }^{4} \mathrm{He}$ lavas is not known, but ref. 20 suggested the involvement of a DUPAL signature - a globe encircling band of isotopic enrichment

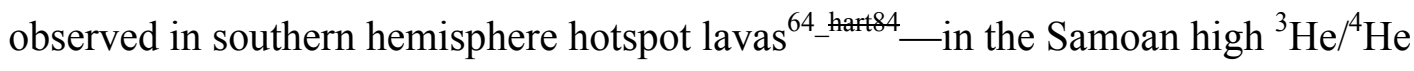
mantle that shifts the ${ }^{143} \mathrm{Nd} /{ }^{144} \mathrm{Nd}$ to lower values than observed in northern hemisphere high ${ }^{3} \mathrm{He} /{ }^{4} \mathrm{He}$ hotspot lavas. The origin of the geochemically-enriched DUPAL signature is not known, but might relate to ancient $(\sim 1.8 \mathrm{Ga})$ subducted material ${ }^{64}$. Thus the unique heavy radiogenic isotopic signature of the Samoan high ${ }^{3} \mathrm{He} /{ }^{4} \mathrm{He}$ plume component may result from the incorporation of ancient subducted material into the high ${ }^{3} \mathrm{He} /{ }^{4} \mathrm{He}$ mantle. 


\section{Extended Data Figure Legends}

Extended Data Figure 1. Sample locations and volcano ages. The range of ages for each location (subaerial or submarine dredge) is provided in a box at the periphery of the map, and a yellow line connects each location with the respective age data; not all samples with geochemical data have age data (indeed, most Samoan samples with geochemical data, submarine and subaerial, do not have age constraints). Dredge locations are labeled with a red line: dredges from the 1999 AVON2/3 cruise aboard the R/V Melville ${ }^{17}$ have dredge numbers less than 100, and dredges from the 2005 ALIA cruise aboard the R/V Kilo Moana ${ }^{18,19,39}$ have dredge numbers greater than 100. Samples collected on land were taken from the five Samoan islands (and are labeled with yellow stars: Savai'i subaerial, Upolu subaerial, Tutuila subaerial, Ta'u subaerial and Ofu subaerial). Malumalu and Vailulu'u seamount ages are based on uranium-series disequilibrium, and therefore maximum ages are provided $^{65,66}$. Upolu subaerial lavas include both rejuvenated series (which bracket the younger limit of ages) and the shield series (which bracket the older limit of ages); poor outcrop exposure on the highly vegetated Samoan islands can make designation of the volcanic stages difficult (particularly if geochemical data is not available for the hand sample), and an average age for the rejuvenated or shield stages on Upolu is therefore not provided. Rejuvenated lavas are present on Tutuila, but ages are not available in the literature. All reported subaerial lavas from Savai'i are rejuvenated, indicating that the island has been covered with a veneer of rejuvenated volcanism ${ }^{21,28}$. 
Rejuvenated volcanism has been observed during historical times on Savai'i, which was last active from 1905 - 1911 (ref. 67); error bars are not provided for the oldest Savai'i subaerial sample in ref. 17. Submarine samples dredged off the coast of Savai'l (D114, D115 and D128), and from Tisa seamount, were dredged distal to the Upo-lineament and may not belong to this lineament. All available ages for Samoan islands and seamounts are provided in the refs $17,18,39,40,41,65,66,68,69$.

Extended Data Figure 2. Panels A through C. $99 \%$ confidence intervals (appearing as "tubes") around the best-fit lines through each of the 4 data groups-Malu lineament (pink tube), Vai lineament (dark blue), subaerial Upo lineament (yellow) and rejuvenated lavas (light blue)—are shown in threedimensional $\mathrm{Pb}$-isotopic space. The composition of the common component region is modeled as an ellipsoid (grey) that is defined by the $2 \sigma$ variance around the average in the $\mathrm{Pb}$-isotopic compositions for samples with ${ }^{3} \mathrm{He} /{ }^{4} \mathrm{He}$ $>20 \mathrm{Ra}$. In three-dimensional Pb-isotopic space, the 99\% confidence intervals around each of the best-fit trend lines overlap with the ellipsoid that encompasses the common component region. Each tube represents an estimate of the error around the best-fit trend to the data defining each geographic lineament. The tube therefore encloses the set of all possible mixing arrays associated with a given geographic lineament. Since all the tubes intersect the ellipsoid of the common component region, statistically a range of mixing arrays exists for each geographic lineament that passes through the common component region. This result is consistent with the 
compositional data of the four lineaments mixing with the high ${ }^{3} \mathrm{He} /{ }^{4} \mathrm{He}$ common component.

Extended Data Figure 3. The isotopic composition of the four Samoan data groups are shown in $\mathrm{Nd}$ and $\mathrm{Pb}$ isotopic spaces. In both panels, the high ${ }^{3} \mathrm{He} /{ }^{4} \mathrm{He}$ common component region (grey field) is modeled by an ellipse that defines the $2 \sigma$ variance around the average of the heavy radiogenic isotopic compositions of Samoan lavas with ${ }^{3} \mathrm{He} /{ }^{4} \mathrm{He}>20 \mathrm{Ra}$. Left panel. The four data groups identified in $\mathrm{Pb}$-isotopic space (Figure 2) are evident in a plot of ${ }^{143} \mathrm{Nd} /{ }^{144} \mathrm{Nd}$ vs ${ }^{206} \mathrm{~Pb} /{ }^{204} \mathrm{~Pb}$. Samples for which $\mathrm{Pb}$-isotopic ratios were measured by high-precision techniques (Pb-spiked samples run by TIMS and samples run using TI-addition by MC-ICP-MS) are shown as large symbols (where estimated $2 \sigma$ external uncertainties are smaller than the symbols $\left.^{17,19,20,21,29,38}\right)$, and unspiked Pb-isotopic TIMS data are shown as small symbols (where estimated $2 \sigma$ external uncertainties are equal to or better than \pm 0.076 for the ${ }^{208} \mathrm{~Pb} /{ }^{204} \mathrm{~Pb}$ ratio, as shown in the figure ${ }^{14,17,48,51}$ ). Right panel. The four data groups identified in Figure 2 are evident in a plot of ${ }^{206} \mathrm{~Pb} /{ }^{204} \mathrm{~Pb}$ vs ${ }^{207} \mathrm{~Pb} /{ }^{204} \mathrm{~Pb}$. Samples for which $\mathrm{Pb}$-isotopic ratios were measured by high-precision techniques (Pb-spiked samples run by TIMS and samples run using TI-addition by MC-ICP-MS) are shown as large symbols (where estimated $2 \sigma$ external uncertainties are smaller than the symbols, except for samples run on the P54 at Carnegie, where estimated $2 \sigma$ external precision error bars are shown on the individual data points, as reported in the Methods); unspiked Pb-isotopic TIMS data are shown as small symbols 
(where estimated $2 \sigma$ external uncertainties are equal to or better than \pm 0.019 and \pm 0.023 for ${ }^{206} \mathrm{~Pb} /{ }^{204} \mathrm{~Pb}$ and ${ }^{207} \mathrm{~Pb} /{ }^{204} \mathrm{~Pb}$, respectively, as shown in the figure). $99 \%$ confidence intervals around the best-fit lines through each data group overlap with the high ${ }^{3} \mathrm{He} /{ }^{4} \mathrm{He}$ common component region. Symbols are the same as in Figure 2 of the main text. The MORB average composition is from ref. 55. The HSDP-2 drill core data is from refs. 24 and 30. See Supplementary Table 4 for a compilation of the Samoan data shown; Alexa data are from ref. 29.

Extended Data Figure 4. Various geochemical signatures show clear trends with increasing distance from the common component region in $\mathrm{Pb}$-isotopic space. Top panel. In a plot of $\mathrm{DPb}_{6-7-8} \mathrm{vs} \mathrm{Ti} / \mathrm{Ti}^{*}$, Samoan lavas with the highest ${ }^{3} \mathrm{He} /{ }^{4} \mathrm{He}$ have the highest $\mathrm{Ti} / \mathrm{Ti}^{*}$ and the lowest $\mathrm{DPb}_{6-7-8}$ values; this follows from an earlier observation that $\mathrm{Ti} / \mathrm{Ti}^{*}$ correlates with ${ }^{3} \mathrm{He} /{ }^{4} \mathrm{He}$ in Samoan lavas, and the high ${ }^{3} \mathrm{He} /{ }^{4} \mathrm{He}$ mantle reservoir has elevated $\mathrm{Ti} / \mathrm{Ti}^{*}$ (ref. 60). $\mathrm{Ti}^{2} \mathrm{Ti}^{*}$ is defined in ref. 19 . Only lavas with $\mathrm{MgO}>7 \mathrm{wt} \%$ are shown, to avoid the affects of fractional crystallization of trace phases that might fractionate the trace element ratios. A sample with high $\mathrm{MnO}$ from Soso (ALIA110-39) is excluded owing to a high degree of alteration. ALIA-115-07, which is highly altered, is also excluded, as are all samples from ALIA Dredge 118. Samples with He concentrations $<10^{-9}$ cc STP/g are excluded. Additionally, only shield-stage lavas are plotted. Middle panel. $\mathrm{DPb}_{6-7-8}$ vs ${ }^{143} \mathrm{Nd} /{ }^{144} \mathrm{Nd} .{ }^{143} \mathrm{Nd} /{ }^{144} \mathrm{Nd}$ shows systematic behavior in each data group moving away from the common component region (i.e., with increasing $\mathrm{DPb}_{6-}$ 
7-8) in $\mathrm{Pb}$-isotope space. Data from subaerial Upo-lineament lavas (yellow) exhibit increasing ${ }^{143} \mathrm{Nd} /{ }^{144} \mathrm{Nd}$ with increasing distance (higher $\mathrm{DPb}_{6-7-8}$ ) from the common component region, and this supports the hypothesis that the subaerial portion of the Upo-lineament samples a depleted mantle (DM) component similar to that found in Alexa seamount and Hawaii. The other data groups (from the rejuvenated lavas and the Vai and Malu volcanic lineaments) all exhibit lower (more enriched) ${ }^{143} \mathrm{Nd} /{ }^{144} \mathrm{Nd}$ with increasing distance from the common component region. Finally, this panel shows that ${ }^{143} \mathrm{Nd} /{ }^{144} \mathrm{Nd}$ exhibits the least amount of variability in the common component region-where $\mathrm{DPb}_{6-7-8}$ is zero-as the four isotopic groups converge on a common component with relatively homogeneous isotopic characteristics. Bottom panel. $\mathrm{DPb}_{6-7-8}$ vs ${ }^{3} \mathrm{He} /{ }^{4} \mathrm{He}$ (also shown in Figure 2 of the main text) is shown here for comparison with the other panels. Symbols are the same as in Figure 2. The MORB average composition is from ref. 55. The HSDP-2 drill core data is from refs. 24 and 30 . When calculating $\mathrm{Ti}^{\mathrm{T}} / \mathrm{Ti}^{*}$, only data obtained by ICP-MS (except Ti, which is measured by X-ray flourescence) are used. See Supplementary Table 4 for sources of the Samoan data; Alexa data are from ref. 29.

Extended Data Figure 5. $(\mathrm{U}+\mathrm{Th}) / \mathrm{Pb}$ vs $\mathrm{Ba} / \mathrm{Th}$. Vai-lineament lavas exhibit the highest $(\mathrm{U}+\mathrm{Th}) / \mathrm{Pb}$ values in Samoa, consistent with a HIMU signature. Such high $(\mathrm{U}+\mathrm{Th}) / \mathrm{Pb}$ values are consistent with the radiogenic $\mathrm{Pb}$-isotopic compositions in Vai-lineament lavas and similar to the high $(\mathrm{U}+\mathrm{Th}) / \mathrm{Pb}$ values observed in HIMU lavas. Samoan rejuvenated lavas, which have an EM1 
signature, have high $\mathrm{Ba} / \mathrm{Th}$ (and $\mathrm{Ba} / \mathrm{Sm}$ and $\mathrm{Ba} / \mathrm{Nb}$ ); this Ba-enrichment matches the positive Ba-anomalies observed in EM1 end-member lavas from Pitcairn ${ }^{29}$. Highly altered samples and samples with low $\mathrm{MgO}$ are excluded (as described in Extended Data Figure 4). Ref. 17 identified Upolu sample U10 as an outlier in many isotope and trace element spaces. Symbols are the same as in Figure 2 of the main text. Only data obtained by ICP-MS are shown. See Supplementary Table 4 for a compilation of the Samoan data shown.

Extended Data Figure 6. The ${ }^{3} \mathrm{He} /{ }^{4} \mathrm{He}$ ratios of Samoan lavas are shown in color (warmer colors represent higher ${ }^{3} \mathrm{He} /{ }^{4} \mathrm{He}$ ) to show the distribution of ${ }^{3} \mathrm{He} /{ }^{4} \mathrm{He}$ ratios in ${ }^{208} \mathrm{~Pb} /{ }^{204} \mathrm{~Pb}$ vs ${ }^{206} \mathrm{~Pb} /{ }^{204} \mathrm{~Pb}$ isotopic space. Lavas with the highest ${ }^{3} \mathrm{He} /{ }^{4} \mathrm{He}$ tend to cluster near the region in $\mathrm{Pb}$-isotopic space where the four $\mathrm{Pb}$-isotopic data groups converge, and lavas with lower ${ }^{3} \mathrm{He} /{ }^{4} \mathrm{He}$ tend to plot farthest from the common component region. Samples with $<10^{-9} \mathrm{cc}$ STP $/ g{ }^{4} \mathrm{He}$ are excluded. See Supplementary Table 4 for a compilation of the Samoan data shown.

\section{References Cited}

31. Carlson, R.W., Czamanske, G., Fedorenko, V., Ilupin, I. A comparison of Siberian meimechites and kimberlites: Implications for the source of high-Mg alkalic magmas and flood basalts. Geochem. Geophys. Geosyst., 7 (2006) Q11014, doi:10.1029/2006GC001342 
32. Galer, S.J.H., Chemical and isotopic studies of crust-mantle differentiation and the generation of mantle heterogeneity, Unpubl. PhD, University of Cambridge, 1986.

33. Abouchami, W., S.J.G. Galer, A. Koschinsky. $\mathrm{Pb}$ and $\mathrm{Nd}$ isotopes in NE Atlantic Fe-Mn crusts: proxies for trace metal paleosources and paleocean circulation, Geochim. Cosmochim. Acta, 63, 1489-1505 (1999).

34. Petrone, C.M., L. Francalanci, R.W. Carlson, L. Ferrari, S. Conticelli. Unusual coexistence of subduction-related and intraplate-type magmatism: $\mathrm{Sr}, \mathrm{Nd}$ and $\mathrm{Pb}$ isotope and trace element data from the magmatism of the San Pedro-Ceboruco graben (Nayarit, Mexico). Chemical Geology, 193, 1-24 (2003).

35. Todt, W. Cliff, R.A., Hanser, A., Hofmann, A.W. Evaluation of a ${ }^{202} \mathrm{~Pb}-{ }^{205} \mathrm{~Pb}$ double spike for high-precision lead isotope analysis, in: A. Basu, S.R. Hart (Eds.), Earth Processes: Reading the Isotopic Code, Geophysical Monograph, vol. 95, 1996, pp. 429437.

36. Hart, S.R., Workman, R.K., Coetzee, M., Blusztajn, J., Ball, L., Johnson, K.T.M. The $\mathrm{Pb}$ isotope pedigree of Western Samoan volcanics: new insights from high-precision analysis by NEPTUNE ICP/MS, EOS 83 (2002) F20.

37. Kurz, M. D., J. Curtice, D. E. Lott III, and A. Solow. Rapid helium isotopic variability in Mauna Kea shield lavas from the Hawaiian Scientific Drilling Project. Geochem. Geophys. Geosyst., 5, (2004). Q04G14, doi:10.1029/2002GC000439.

38. Jackson, M.G. et al. The Samoan hotspot track on a "hotspot highway": Implications for mantle plumes and a deep Samoan mantle source. Geochem. Geophys. Geosyst. 11, 
2010. doi:10.1029/2010GC003232.

39. Koppers et al. Age systematics of two young en echelon Samoan volcanic trails. Geochem. Geophys. Geosyst. 12 (2011). Q07025, doi:10.1029/2010GC003438

40. Natland, J. H., \& D. L. Turner (1985), Age progression and petrological development of Samoan Shield volcanoes: Evidence from K-Ar ages, lava compositions and mineral studies, in Geological Investigations of the Northern Melanesian Borderland, Earth Sci. Ser., vol 3, edited by T. M. Brocker, pp. 139-172, Circum-Pac. Counc. for Energy and Miner. Resour., Houston, Tex.

41. Mcdougall, I. (1985), Age and evolution of the volcanos of Tutuila, American Samoa. Pac. Sci. 39, 311-320 (1985)

42. Stolper, E.M., \& DePaolo, D.M. Introduction to special section: Hawaii Scientific Drilling Project. J. of Geophys Res 101, 11593-11598 (1996).

43. Kear, D., \& Wood, B.L. The geology and hydrology of Western Samoa: New Zealand Geological Survey Bulletin 63 (1959).

44. Palacz, Z.A., \& Saunders, A.D. Coupled trace element and isotope enrichment in the Cook-Austral-Samoa islands, southwestPacific. Earth Planet. Sci. Lett. 79 270-280 (1986).

45. McDonough, W. \& Chauvel, C. Sample contamination explains the Pb isotopic composition of some Rurutu island and Sasha seamount basalts. Earth Planet. Sci. Lett. 105, 396-404 (1991). 
46. Hawkins, J.W., and J. H. Natland. Nephelinites and basanites of the Samoan linear volcanic chain: Their possible tectonic significance, Earth Planet. Sci. Lett. 24, 427-439 (1975). doi:10.1016/0012-821X(75)90150-8.

47. White, W. M. \& Hofmann, A. W. Sr and Nd isotope geochemistry of oceanic basalts and mantle evolution. Nature 296, 821-825 (1982).

48. Wright, E., White, W.M. (1986). The origin of Samoa: new evidence from Sr, Nd, and $\mathrm{Pb}$ isotopes. Earth Planet. Sci. Lett. 81, 151-162 (1986/87).

49. Workman, R.K., Eiler, J.M., Hart, S.R., Jackson, M.G., Oxygen isotopes in Samoan lavas: Confirmation of continent recycling. Geology 36, 551-554 (2008).

50. Hanyu, T., Tatsumi, Y., Senda, R., Miyazaki, T., Chang, Q., Hirahara, Y., Takahashi, T., Kawabata, H., Suzuki, K., \& Kimura, J.-I. Geochemical characteristics and origin of the HIMU reservoir: A possible mantle plume source in the lower mantle. Geochem. Geophys. Geosyst. 12 (2011) Q0AC09, doi:10.1029/2010GC003252

51. Hauri, E.H., \& Hart, S.R. Re-Os isotope systematics of HIMU and EMII oceanic island basalts from the south Pacific ocean. Earth and Planet. Sci. Lett. 114, 353-371 (1993).

52. Hauri, E.H., Hart, S.R. Rhenium abundances and systematics in oceanic basalts, Chem. Geol. 139, 185-205 (1997).

53. Hofmann, A. W. \& White, W. M. Mantle plumes from ancient oceanic crust. Earth Planet. Sci. Lett. 57, 421-436 (1982).

54. Cabral, R.A. et al. Anomalous sulphur isotopes in plume lavas reveal deep mantle 
storage of Archaean crust. Nature 490, 490-493 (2013).

55. Gale, A., C. A. Dalton, C. H. Langmuir, Y. Su, and J.-G. Schilling. The mean composition of ocean ridge basalts. Geochem. Geophys. Geosyst., 14, 489-518 (2013). doi:10.1029/2012GC004334.

56. Graham, D.W., Jenkins, W.J., Schilling, J.-G., Thompson, G., Kurz, M.D., \& Humphris, S.E. Helium isotope geochemistry of mid-ocean ridge basalts from the South Atlantic. Earth Planet Sci. Lett. 110, 133-147 (1992).

57. Parai, R., Mukhopadhyay, S., \& Lassiter, J.C. (2009). New constraints on the HIMU mantle from neon and helium isotopic compositions of basalts from the Cook-Austral Islands. Earth Planet. Sci. Lett. 277, 253-261 (2009).

58. Hanyu, T., \& Kaneoka, I., The uniform and low ${ }^{3} \mathrm{He} /{ }^{4} \mathrm{He}$ ratios of HIMU basalts as evidence for their origin as recycled materials. Nature, 390, 273-276 (1997).

59. Honda, M., \& Woodhead, J.D. A primordial solar-neon enriched component in the source of EM-I-type ocean island basalts from the Pitcairn Seamounts, Polynesia. Earth Planet. Sci. Lett. 236, 597-612 (2005).

60. Jackson, M.G., Hart, S.R., Saal, A.E., Shimizu, N., Kurz, M.D., Blusztajn, J., \& Skovgaard, A. Globally elevated titanium, tantalum, and niobium (TITAN) in ocean island basalts with high ${ }^{3} \mathrm{He} /{ }^{4} \mathrm{He}$. Geochem. Geophys. Geosyst. 9 (2008). doi:10.1029/2007GC001876. 
61. S.R. Hart, \& Jackson, M. Ta'u and Ofu/Olosega volcanoes: The "Twin Sisters"' of Samoa, their P, T, X melting regime, and global implications. Geochem. Geophys.

Geosyst. (2014). doi: 10.1002/2013GC005221

62. Farley, K.A. Rapid cycling of subducted sediments into the Samoan mantle plume. Geology, 23, 531-534 (1995).

63. Class, C., \& Goldstein, S.L. Evolution of helium isotopes in the Earth's mantle. Nature 436, 1107-1112 (2005)

64. Hart, S.R. A large-scale isotope anomaly in the Southern Hemisphere mantle. Nature 309, 753-757 (1984).

65. Sims, K.W.W. et al. ${ }^{238} \mathrm{U}-{ }^{230} \mathrm{Th}-{ }^{226} \mathrm{Ra}-{ }^{210} \mathrm{Po},{ }^{232} \mathrm{Th}^{2}{ }^{228} \mathrm{Ra}$, and ${ }^{235} \mathrm{U}-{ }^{231} \mathrm{~Pa}$ constraints on the ages and petrogenesis of Vailulu'u and Malumalu lavas, Samoa. Geochem. Geophys. Geosyst. 9, Q04003 (2008). doi:10.1029/2007GC001651.

66. Hart, S.R. et al. Vailulu'u undersea volcano: The new Samoa. Geochem. Geophys. Geosys. 1, (2000). doi:10.1029/2000GC000108.

67. Anderson, T. The volcano of Matavanu in Savaii. Q. J. Geol. Soc. London 66, 621639 (1910).

68. Matsuda, J.I., Notsu, K., Okano, J., Yaskawa, K., \& Chungue, L. Geochemical implications from $\mathrm{Sr}$ isotopes and $\mathrm{K}$-Ar age determinations for the Cook-Austral Islands chain. Tectonophysics 104, 145-154 (1984).

69. McDougall, I. Age of volcanism and its migration in the Samoa Islands, Geol. Mag. 147, 705-717 (2010). doi:10.1017/s0016756810000038. 


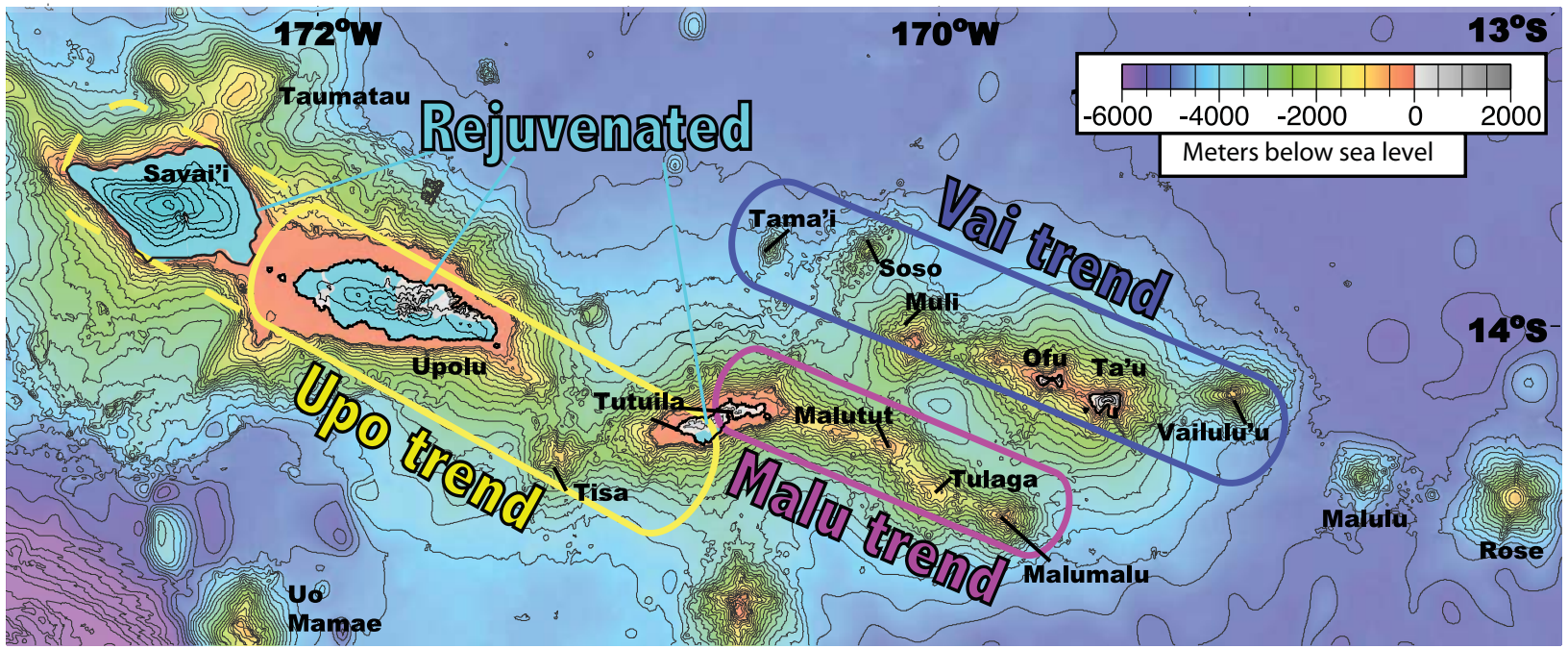

Jackson Fig. 1 


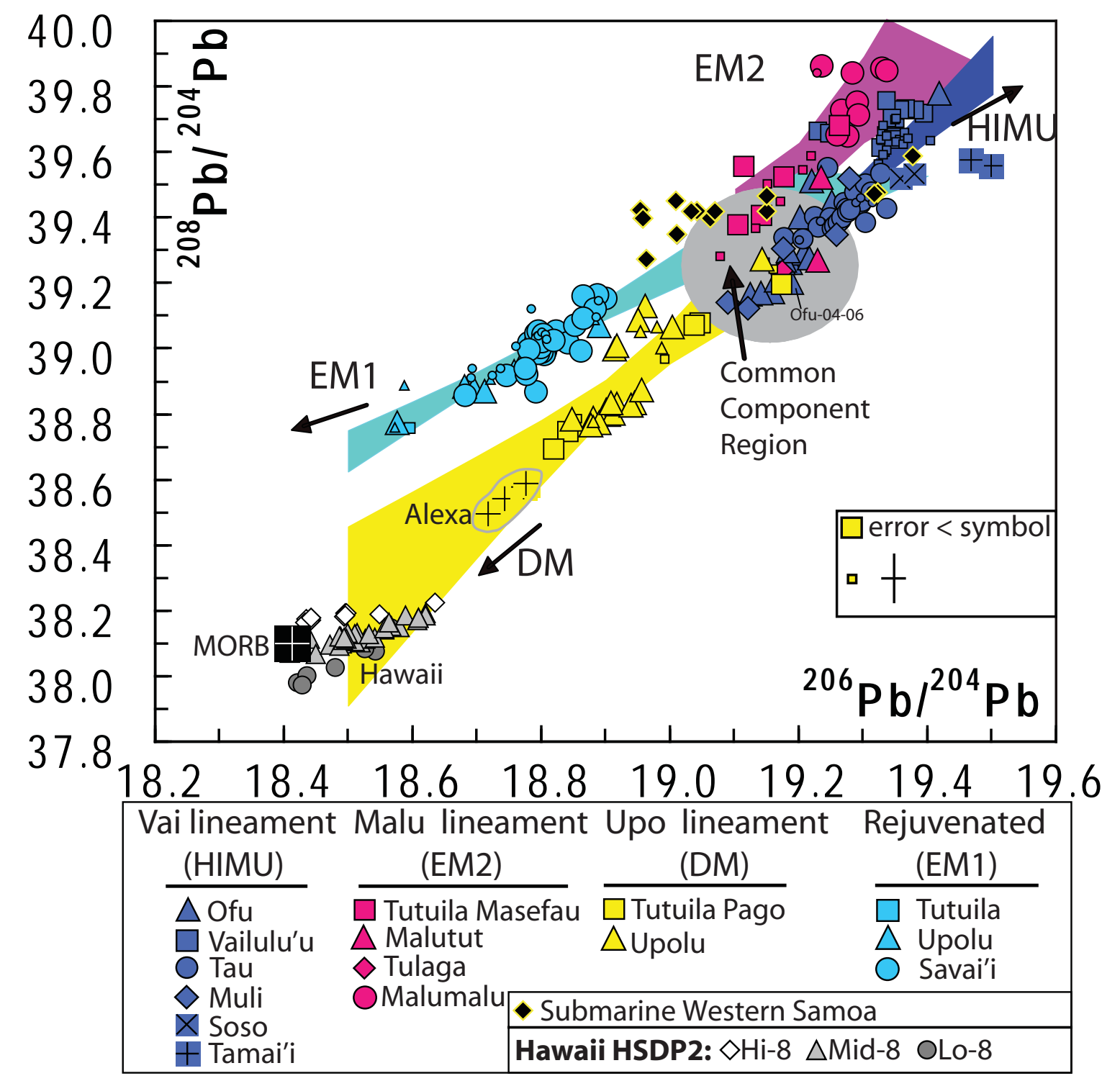

Jackson Fig. 2 


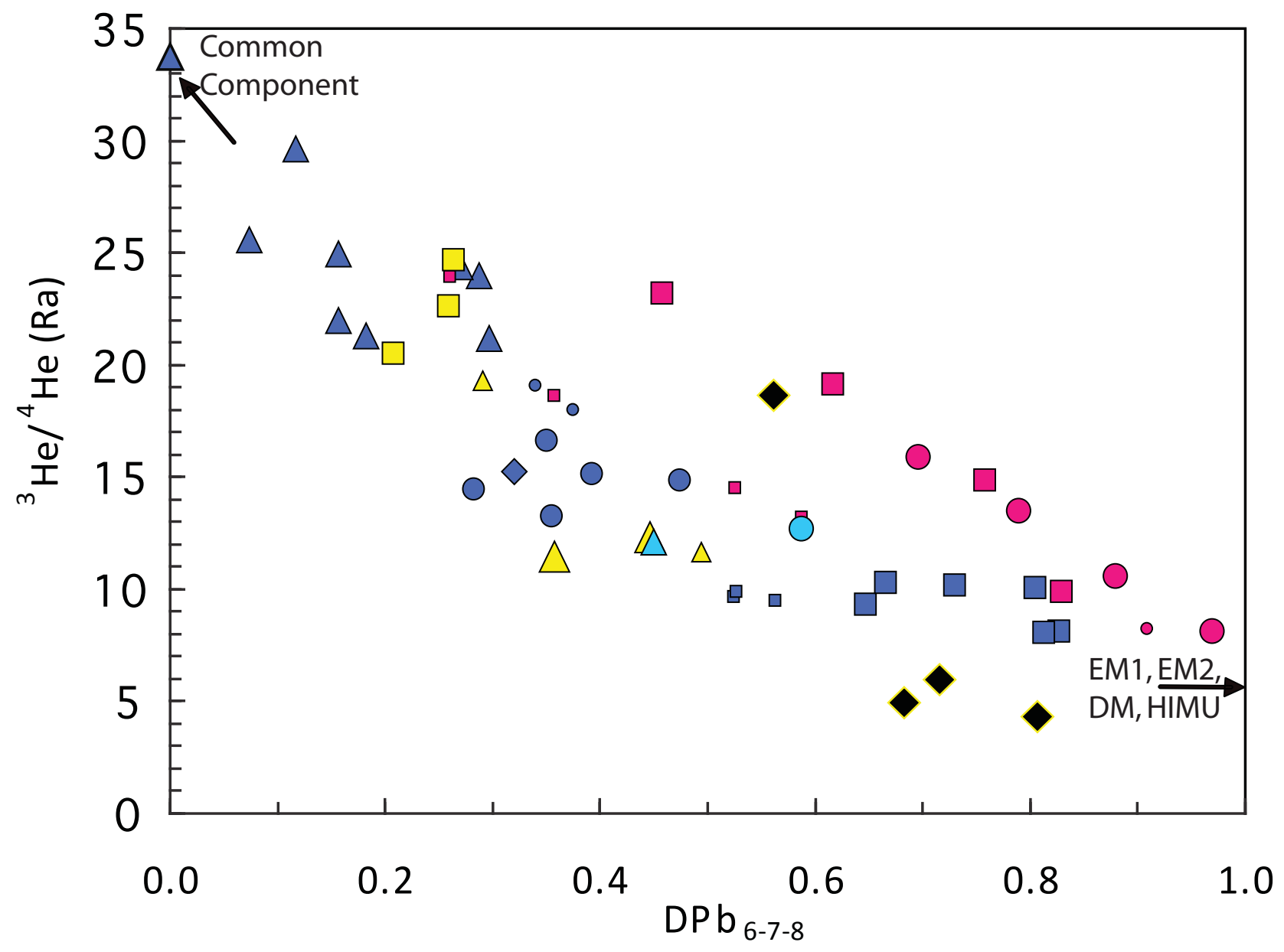

Jackson Fig. 3 


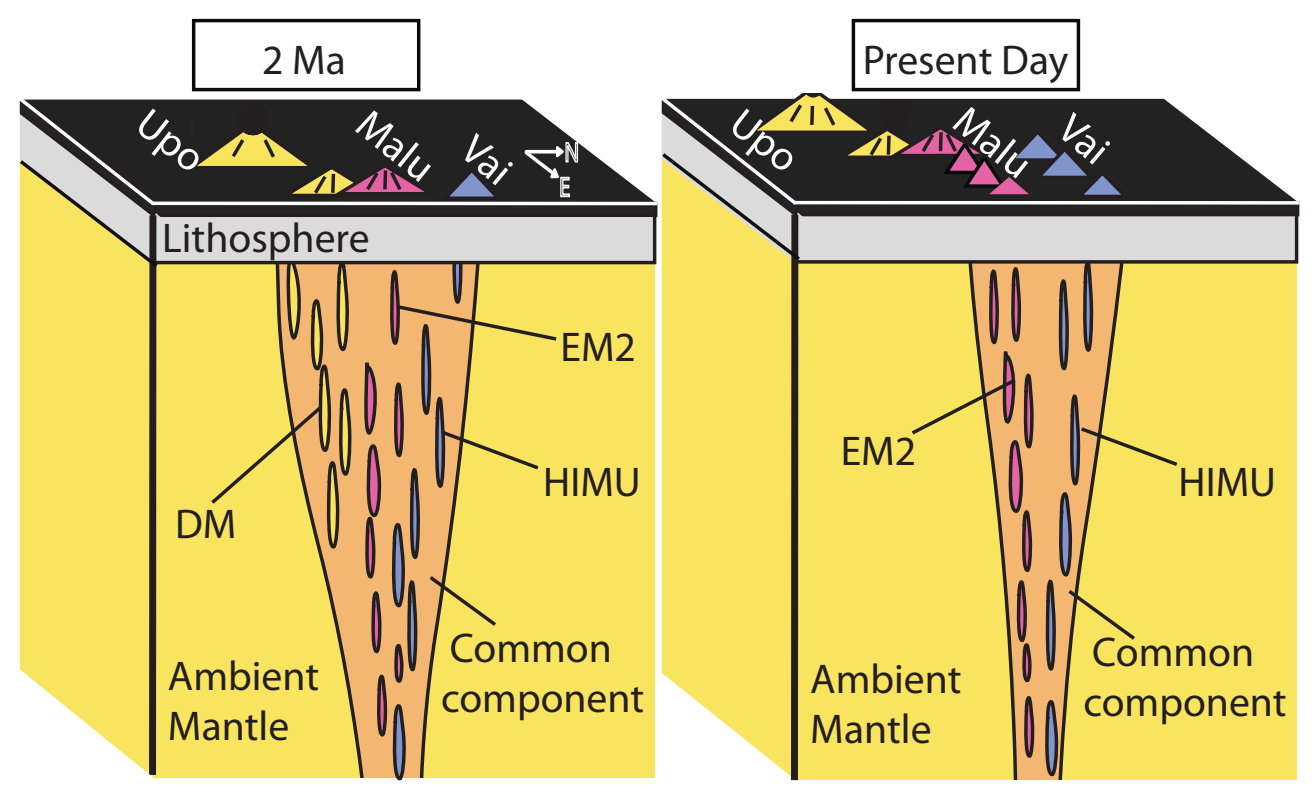

Jackson Fig. 4 


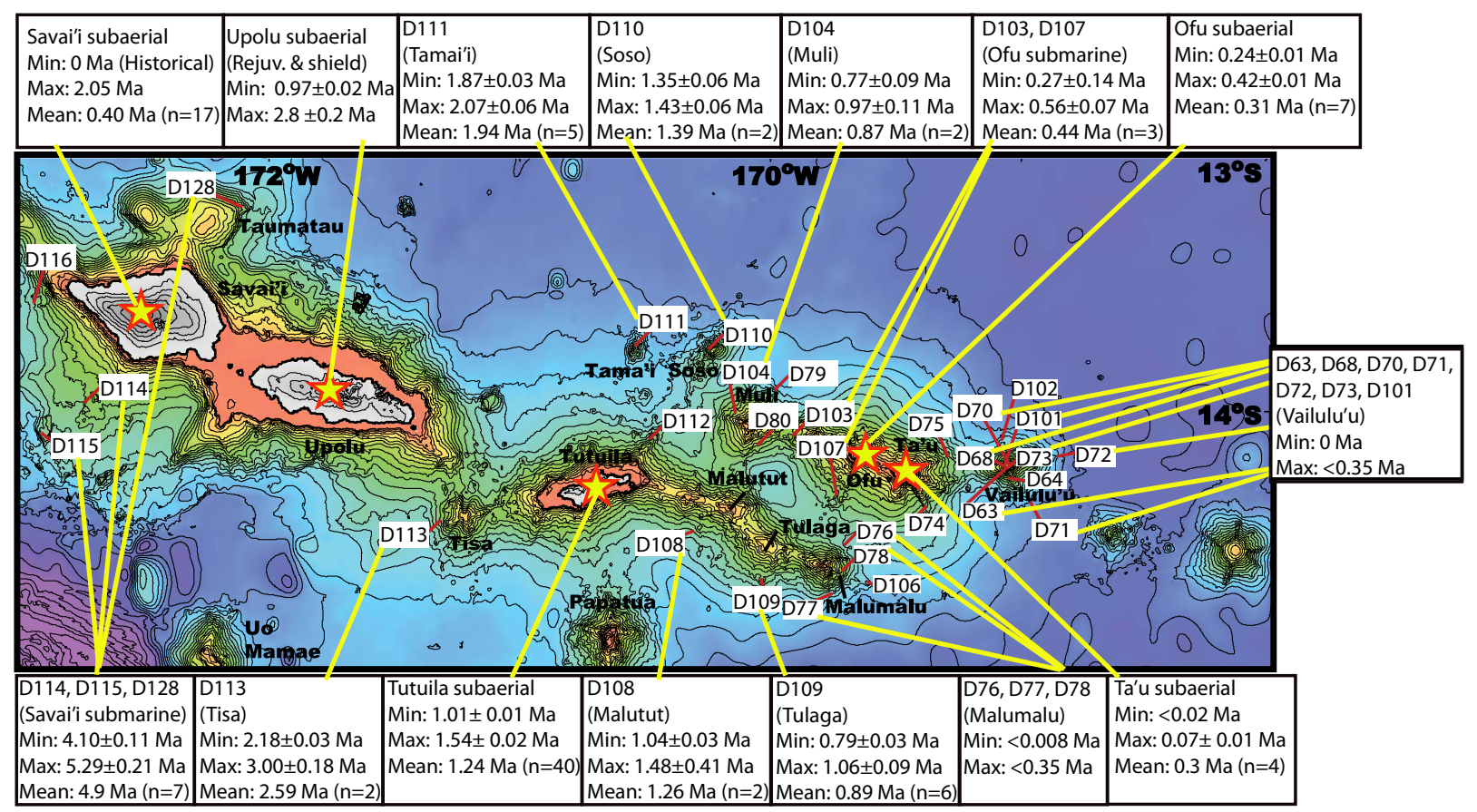

Extended Data Fig. 1 

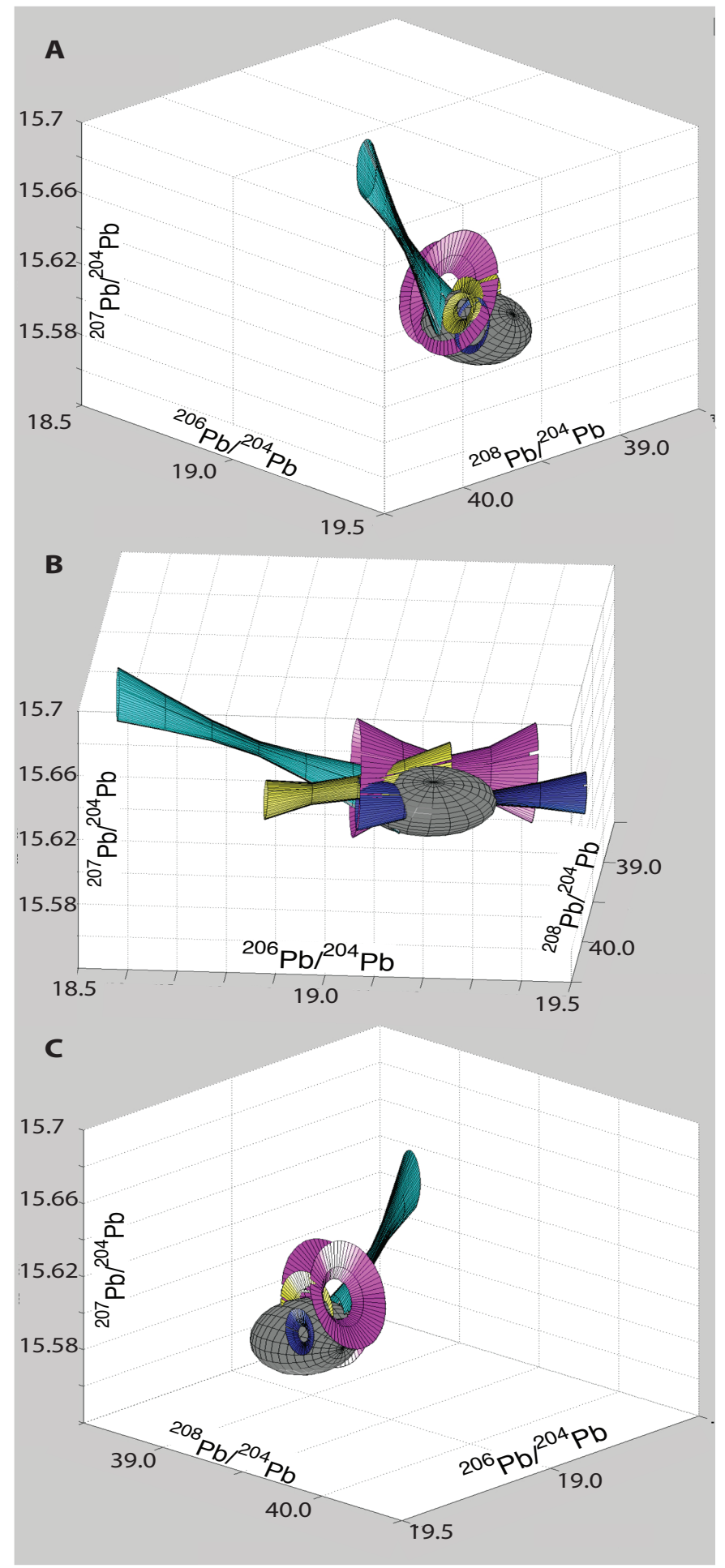

Extended Data Fig. 2 

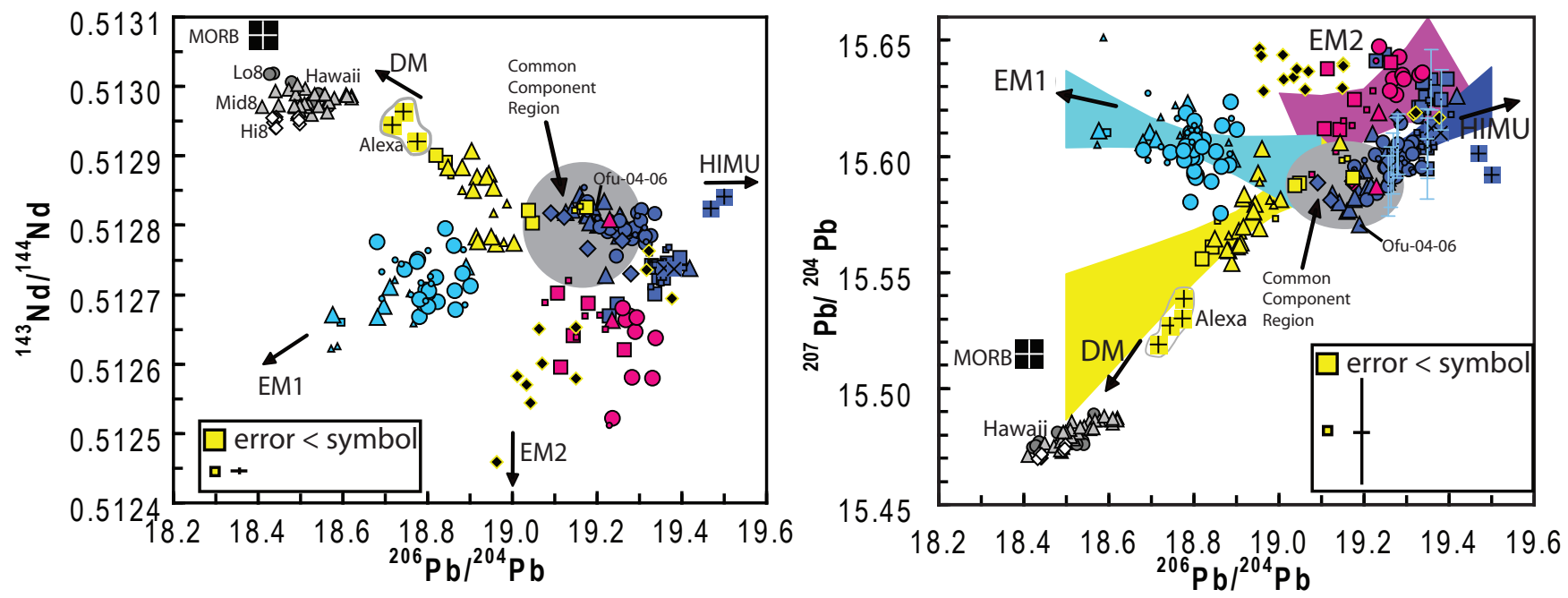

\begin{tabular}{|c|c|c|c|}
\hline $\begin{array}{l}\text { Vai lineament } \\
\text { (HIMU) }\end{array}$ & $\begin{array}{l}\text { Malu lineament } \\
(\mathrm{EM} 2)\end{array}$ & $\begin{array}{l}\text { Upo lineament } \\
\text { (DM) }\end{array}$ & $\begin{array}{l}\text { Rejuvenated } \\
\text { (EM1) }\end{array}$ \\
\hline \multirow{3}{*}{$\begin{array}{l}\triangle \text { Ofu } \\
\square \text { Vailulu'u } \\
\bigcirc \text { Tau } \\
\diamond \text { Muli } \\
\text { X Soso } \\
\text { \# Tamai'i }\end{array}$} & $\begin{array}{l}\text { Tutuila Masefau } \\
\triangle \text { Malutut } \\
\diamond \text { Tulaga }\end{array}$ & $\begin{array}{l}\square \text { Tutuila Pago } \\
\triangle \text { Upolu }\end{array}$ & $\begin{array}{l}\square \text { Tutuila } \\
\triangle \text { Upolu } \\
\bigcirc \text { Savai'i }\end{array}$ \\
\hline & \multicolumn{3}{|c|}{ OMalumalu $>$ Submarine W. Samoa } \\
\hline & & \multicolumn{2}{|c|}{ Hawaii HSDP2: $\diamond$ Hi-8 $\triangle$ Mid-8 OLo-8 } \\
\hline
\end{tabular}

Extended Data Fig. 3 


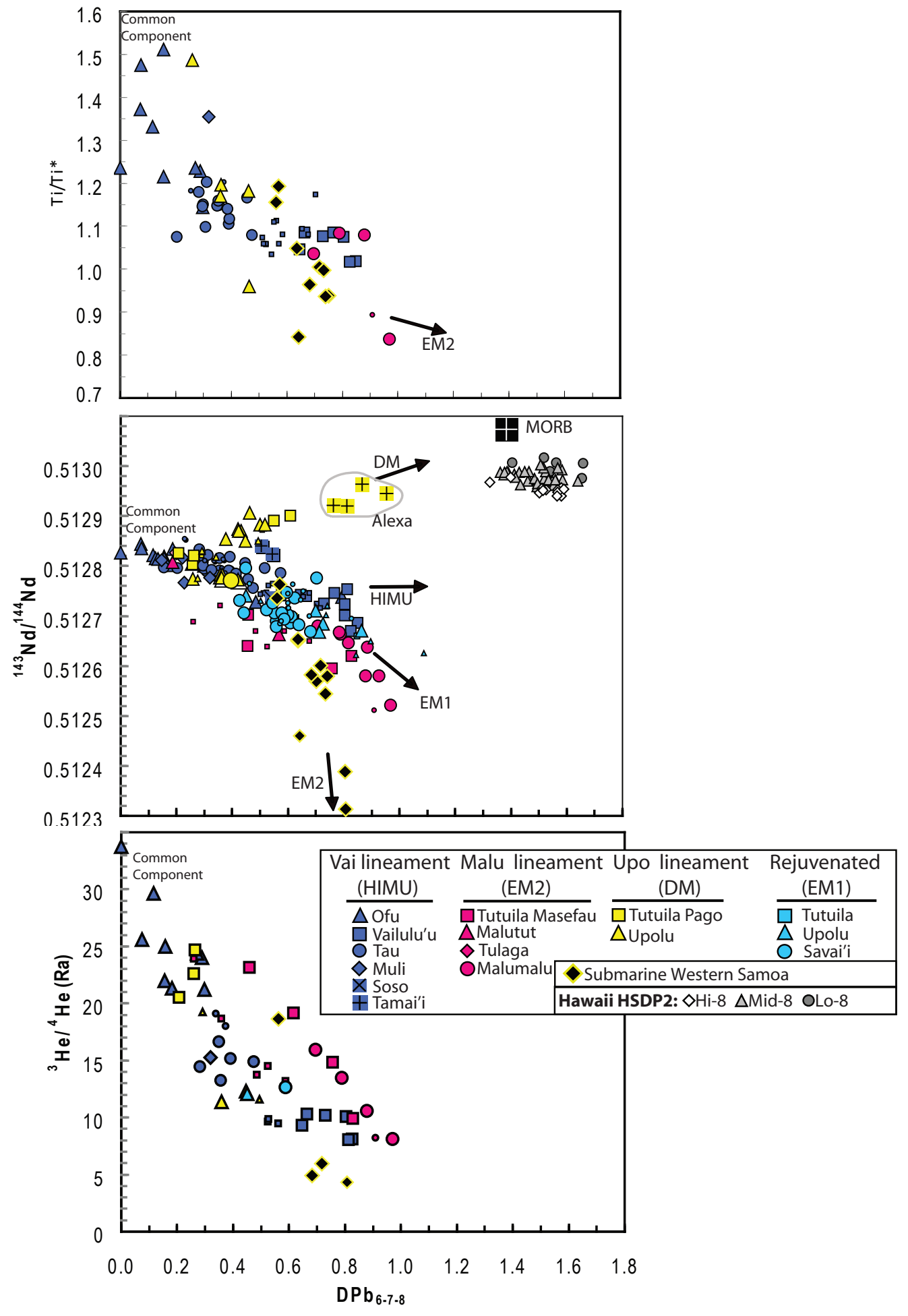

Extended Data Fig. 4 


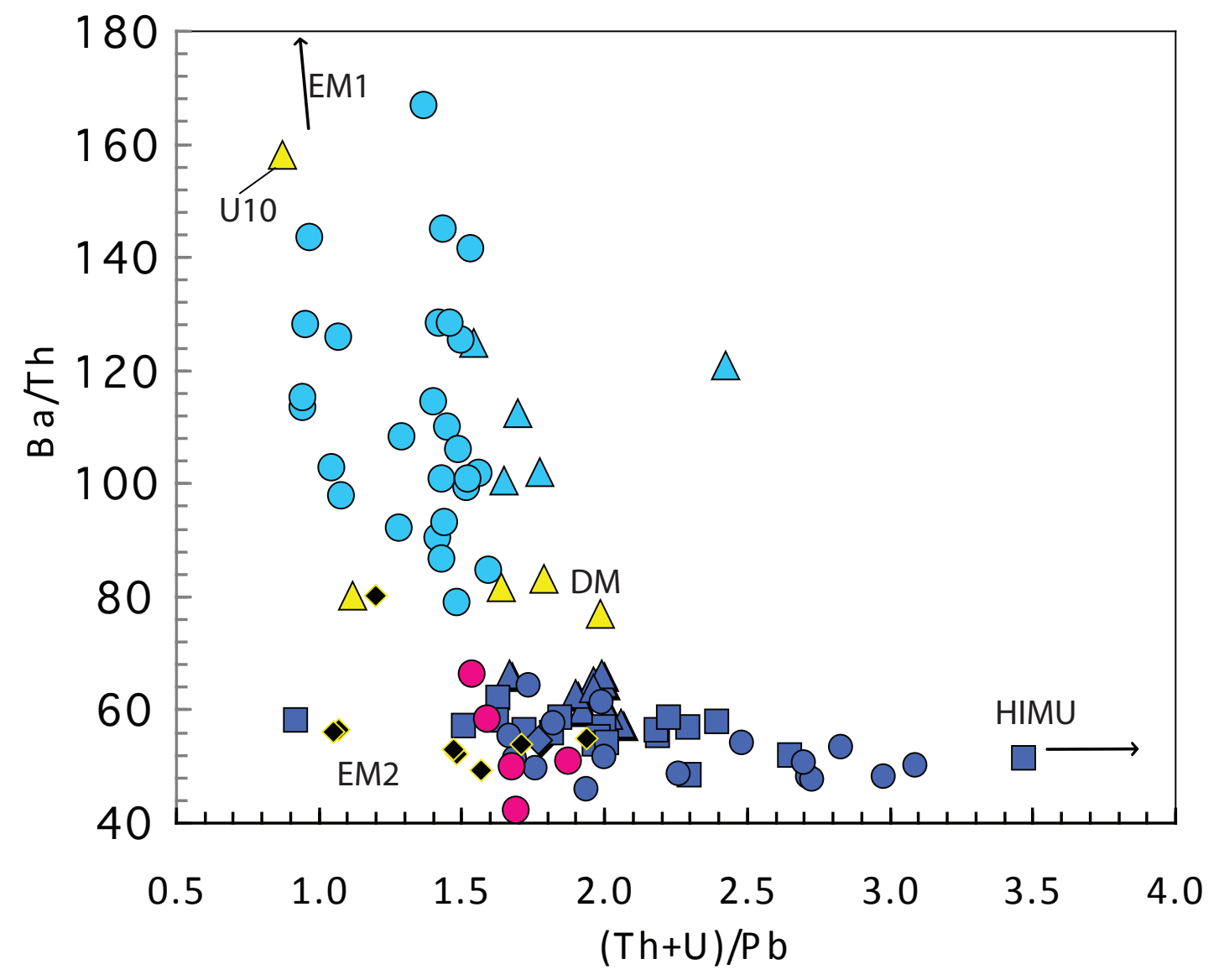

Extended Data Fig. 5 


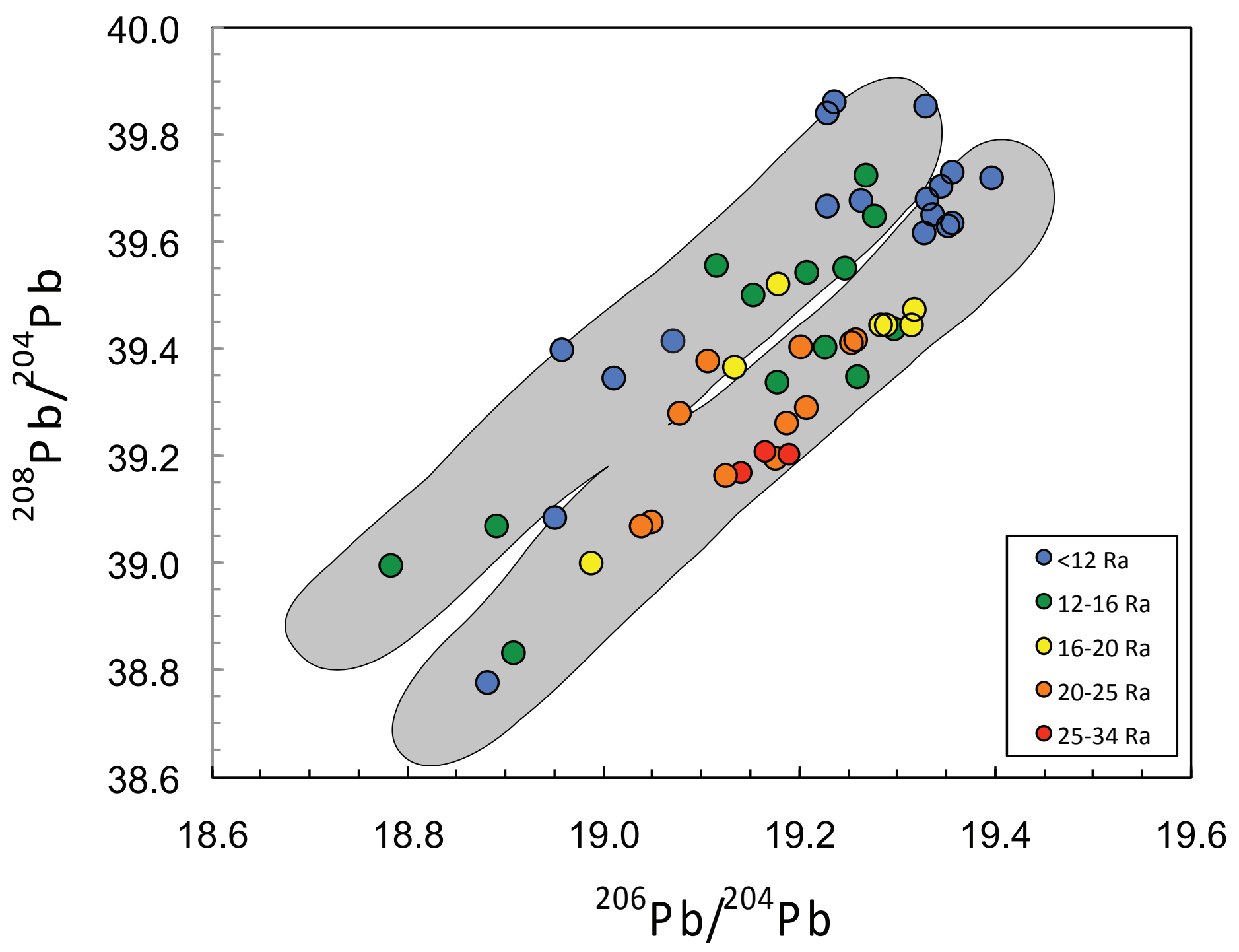

Extended Data Fig. 6 